\title{
Qur'anic Ethics for Environmental Responsibility: Implications for Business Practice
}

\author{
Akrum Helfaya \\ Keele University (UK) and Damanhour University (Egypt) \\ Keele ST5 5BG \\ England, UK \\ a.n.ekara.helfaya@keele.ac.uk
}

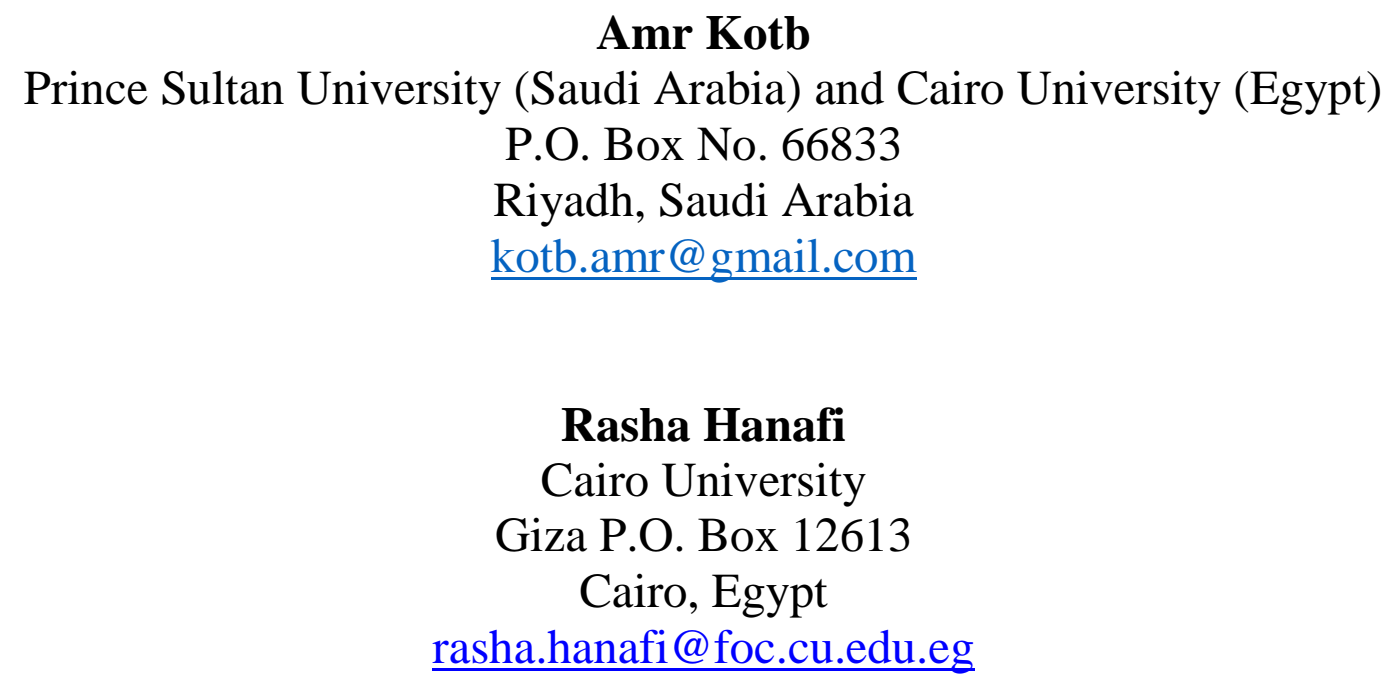

This is the final peer reviewed version of the following article: [Helfaya, A., Kotb, A. \& Hanafi, R. (2016) Qur'anic Ethics for Environmental Responsibility: Implications for Business Practice. Journal of Business Ethics], which has been published in final form at [DOI: 10.1007/s10551016-3195-6]. This article may be used for non-commercial purposes in accordance with Springer terms and conditions for self-archiving. 


\title{
Qur'anic Ethics for Environmental Responsibility: Implications for Business Practice
}

\begin{abstract}
Despite the growing interest in examining the role of religious beliefs as a guide towards environmental conscious actions, there is still a lack of research informed by an analysis of divine messages. This deficiency includes: the extent to which ethics for environmental responsibility are promoted within textual divine messages; types of environmental themes promoted within the text of divine messages; and implications of such religious environmental ethics for business practice. The present study attempts to fill this gap by conducting a thorough content analysis of environmental themes within the divine message of Muslims (the Qur'an) focusing on their related ethical aspects and business implications. The analysis has revealed 675 verses in 84 chapters throughout all 30 parts of the Qur'an, with environmental content relating to the core components of the natural world, i.e. human beings, water, air, land, plants, animals, and other natural resources. This environmental content and its related ethics are grounded on the belief that humans are vicegerents of God on the earth and their behaviours and actions are motivated by earthly and heavenly rewards. Implications of these findings for different sectors/businesses are also highlighted.
\end{abstract}

Keywords Business practice implications. Corporate social responsibility. Environmental responsibility. Environmental ethics. Islam. Qur'an. 


\section{Introduction}

Over recent decades, environmental responsibility (ER) has been a subject of intense interest in corporate social responsibility (CSR) literature. Despite the fact that the aim of this plethora of research was to better understand corporate environmental behaviour and to urge businesses to take their responsibility towards the environment seriously, the outcome is still not satisfactory. For example, environmental problems (e.g. carbon emissions, air and water pollution, wastewater, waste energy, landfill, soil erosion, deforestation, etc.) are still prevailing if not escalating (Babcock, 2009b; Campbell, 2006; Gray et al., 1995a; Hsieh, 2004; Kula, 2001). Supporting this view, some research (e.g. Lu, 2009; Lutz, 2002) reveals that corporations may use the ER notion through the process of impression management, ${ }^{1}$ to achieve business rewards (e.g. legitimisation, cost reduction, profit and market share increase, customer satisfaction, corporate image/reputation enhancement, etc.) rather than making a real positive contribution to the natural environment.

While religious belief can be a powerful influence on the behaviour of individuals, groups, and society as a whole (Hope and Jones, 2014), a relatively new line of ER literature has emerged, revealing a move towards the three monotheistic religions (i.e. Abrahamic religions: Judaism, Christianity, and Islam) and their impact upon behaviours and actions of individuals/groups for the welfare of society and environment (e.g. Beekun and Badawi, 2005; Brammer et al., 2007; Graafland et al., 2006; Hope and Jones, 2014; Kamla et al., 2006; Kim et al., 2009; Oumlil and Balloun, 2009; Platonova, 2013; Ramasamy et al., 2010; Rice, 1999, 2006; Schouten et al., 2014; Srnka et al., 2007; Zulfikar 2012). Yet, there is still a lack of empirical evidence on the following: the extent to which ER ethics are promoted within divine textual messages, types of environmental themes contained within such holy texts, and implications of these ethics for business practices. Importantly, to the best of the authors' knowledge, no single prior study has investigated these issues within the religion of Islam based on a thorough content analysis of its holy book: the Qur'an (a primary source of the religion). The present study, therefore, attempts to address this gap in the business ethics literature.

The empirical study has revealed seven environmental thematic groups promoted within the Qur'anic text (i.e. human beings, water, air, land, plants, animals, and other natural resources), grounded on the belief that the human being is a vicegerent of God on the earth, and that all elements, species, habitats, and ecosystems are

\footnotetext{
${ }^{1}$ From a psychological perspective, Leary and Kowalski (1990, p. 34) refer to "impression management" (may also be called self-presentation) as "the process by which individuals [and/or corporations] attempt to control the impressions others form of them".
} 
part of the perfect (divinely ordained balanced) universe created by God. In Islam, worshipping God does not just consist of performing specified rituals (e.g. prayers, paying charity, fasting during the month of Ramadan, etc.). These worshipping activities must be performed in accordance with the ultimate goal of the Islamic life: looking after the universe with all of its components and improving life for oneself and others. Therefore, the seven identified Qur'anic themes of ER have many ethical aspects (e.g. the responsibility to use, not abuse). Each of these has several implications for business practice (e.g. eliminating abuse of women and child labour, preventing exploitation of natural resources, reducing wastewater, decreasing air pollution and noise, etc.), achieving prosperity for the "3Ps" (profit, people, and planet).

This study contributes to the business ethics literature in three ways. Firstly, this is the first study to examine the relationship between Islamic ethics and the ER concept based on a comprehensive textual analysis of the Qur'an. Secondly, the analysis results in seven unique ER themes, which go beyond those covered in the extant literature, thus providing a better understanding of the components of the environmental responsibility from a divine (Qur'anic) perspective. Finally, while existing literature generally links the Islamic ethics of ER and business practices, this study focuses on the Qur'anic environmental themes, their related ethical aspects, and the relevant business implications for different industrial sectors.

The following section provides a background for the study, including an overview of Islam and a discussion on the corporate and Islamic views of the ER concept, leading to the research questions. This will be followed by the research design. Then, empirical results will be presented. The penultimate section discusses business implications of the findings before the paper concludes with limitations and directions for future research.

\section{Background and Development of Research Questions}

\section{Islam: An Overview}

Islam is the most rapidly growing religion in the world with approximately 1.6 billion followers in 2010 , representing $23 \%$ of the world's population. This figure is expected to be 2.8 billion in 2050 (30\% of the world's population), making it the second largest religion after Christianity and comprising the majority of the population in 49 countries (Pew Research Center, 2012). In its original language, Arabic, "Islam" means "submission to the will of God". Lewis (2001, p. 104) explains that the origins of the terms "Islam" and 
"Muslims" are in the root s-1-m, and "the term 'aslama' means to submit oneself with complete peace of mind or to give oneself up to God, and it is from this that the word Muslim derives".

As believed by Muslims, Islam is the conclusion of the monotheistic religions, and the Qur'an is the final revelation to the human being. According to Islamic teachings, the Qur'an was sent as a constitution to all humanity, organising and governing life, work, and relationships. Accordingly, both the Qur'an (the word of God) and the Sunnah (the words and actions of the prophet Mohammed) are the two primary sources of the Islamic law - Shari'ah. The prophet Mohammed is quoted as saying "I have left amongst you two things which, if you hold fast to them, you will never stray: the Book of Allah and my Sunnah". While the Qur'an provides general rules, the Sunnah defines and clarifies these rules in references to the sayings (qaul) of the prophet Mohammed, his deed (fi'l) and the act he confirmed (iqrar).

Shari'ah has two major elements: worship (ibadah) and transaction (muamalah). The former refers to the worship relationship between humans and God, while the latter is concerned with the daily life relationship between individuals. Both elements work together to promote the wellbeing of all human beings, achieving five objectives (known as maqasid) of Shari'ah to protect: faith (din), human selves (nafs), intellect (aql), posterity (nasl), and wealth (maal) (Al-Ghazali, 1901; Al-Juwayni, 1979; Al-Najjar, 2008; Dusuki and Abdullah, 2007). Shari'ah states four principles to govern socio-economic life: unity (tawhid), in which individual actions must conform to an integrated whole; equilibrium (al'adlwalihsan), in which individuals have the freewill to act without harming the other; freewill (ikhtiyar), by which an individual's freedom is controlled by a broader framework of duty to the community; and responsibility (fardh), by which individuals and community have the responsibility to use and dispose of properties and wealth in a responsible manner (Al-Qaradawi, 1985, 2000; Kamla et al., 2006; Rice, 1999; Rizk, 2014). Hence, as a core part of their faith, Muslims must discharge their ethical responsibility towards society, including the environmental world.

\section{Corporate Environmentalism vs. Religious Environmentalism}

Since the 1992 UN Earth Summit in Rio de Janeiro (or possibly a little earlier than this), environmental concerns have been the centre of an extensive global debate drawing the attention of international organisations, policy makers, and academics, examining how businesses can genuinely contribute to what Milne and Gray (2013, p. 13) called "a transition to an ecologically sustainable society" (Gray, 2010; Jackson, 
2009; Porritt, 2007; Savitz, 2006). In response, numerous and diverse approaches have been developed and adopted (under the ER notion) by businesses to address societal concerns about the environment, representing novel movements towards "an ecologically sustainable society". Among these are corporate environmentalism and triple bottom line (TBL or 3BL), as core and dominant approaches that continue to pervade organisational management and business reporting (Banerjee, 2001, 2002; Freeman et al., 2000; Goel, 2010; Henriques, 2007; Milne and Gray, 2013; Savitz, 2006).

In contrast to the traditional social paradigm of limitless growth and infinite natural resources (Egri and Pinfield, 1996), corporate environmentalism has emerged as a reformist approach to address environmental issues facing businesses through the development of environmental management strategies (Banerjee, 2001, 2002; Freeman et al., 2000). Banerjee (2002, p. 181) defines corporate environmentalism as "the organizationwide recognition of the legitimacy and importance of the biophysical environment in the formulation of organization strategy, and the integration of environmental issues into the strategic planning process”. In this sense, two main themes of corporate environmentalism were found in the literature: corporate environmental orientation and corporate environmental strategy. In recognition of stakeholder interests, corporate environmental orientation involves an internal focus on the company's values, standards of ethical behaviour, and commitment to environmental protection (Shrivastava, 1995; Zeffane et al., 1995; Freeman et al., 2000), as well as being responsive to stakeholder interests and being a good corporate citizen (Gladwin et al., 1995; Hart, 1995; Menon and Menon, 1997). On the other hand, when focusing on developing a corporate competitive advantage, corporate environmental strategy considers the strategic implications of environmental issues for organisations, reflecting the degree to which environmental issues are integrated into the strategic planning process (Banerjee, 2002; Jennings and Zandbergen, 1995; Shrivastava, 1995; Zeffane et al., 1995).

In a further development, based on the seminal work of Paul Hawken's The Ecology of Commerce (1992, 1993), Jermier et al. (2006) refer to a new development in the green politics, namely new corporate environmentalism, which goes beyond environmental laws and regulatory compliance (the traditional corporate environmentalism). They defined the new corporate environmentalism as "rhetoric concerning the central role of business in achieving both economic growth and ecological rationality and as a guide for management that emphasizes voluntary, proactive control of environmental impacts in ways that exceed or go beyond environmental laws and regulatory compliance" (Jermier et al., 2006, p. 618). Forbes and Jermier 
(2010, p. 466) argue that this advanced (voluntary) version of corporate environmentalism places the commercial enterprise in the leadership role of initiatives aimed at a self-regulation position, thus situating the control of environmental impacts in the hands of "individual corporations, value chain requirements, industry and trade associations, third party commercial certification, sectorial guidelines and covenants, government incentive programs and other alliances, rather than government regulatory agencies" (see also Andrews, 1998).

As a tool of measuring and communicating the corporate environmentalism performance (with profitability and social capital), the notion of the triple bottom line has emerged (Elkington, 1997; Henriques, 2007), aimed at enlarging responsibility of businesses in "contributing to both the well-being of society in general and the integrity of the natural environment" (Ekwueme et al., 2013, p. 82). The TBL approach responds to stakeholder demands that companies be accountable for and substantiate their membership in society, as a warning mechanism, thus allowing them to respond faster to changes in stakeholders' behaviour/demand, and incorporate the new changes into the strategy before they hit the bottom (economic) line (Norman and MacDonald, 2004). Such corporate reporting takes businesses beyond the traditional economic logic of maximising profit by responding to all company stakeholders' demands/interests and reflecting its environmental and social responsibilities, thus acting as an ethical responsible corporate citizen (Abeng, 1997).

Whereas corporate environmentalism and TBL approaches come under the umbrella of the corporate ER, motives underlying these approaches are varied. While social contract theory has been used as a means of viewing and articulating the relationship between corporations and the community (Donaldson, 1982), stakeholder theory viewed the world from the perspective of the business that manages and supports its stakeholders' interests, thus companies secure long-term survival as well as economic successes (Gray et al., 1995b; Freeman et al., 2010). Further, legitimacy theory provides insights into the motives behind companies that adopt such environmental approaches, suggesting that the ER concept is a form of reaction to factors within the company's natural environment and is undertaken with the aim of legitimising the company's actions. Interpreted in the light of the institutional theory, this is a strategic mechanism to add value to the corporation's reputational capital, and in turn, achieve its economic objectives (Dusuki, 2008). Accountability perspective delineates three possible groups (i.e. shareholders, stakeholders, and the public) that the company should be accountable for and consider ER actions towards (Benston, 1982; Brown et al., 2010). 
Based on the aforementioned, the ER concept is often regarded by businesses as a mechanism to soften the company's image and reputation by presenting it as humane, benevolent, and environmentally responsible. It is therefore merely a means to ingratiate capitalism with a rightly mistrustful public. Thus, most of the motives/theories underpinning the ER approaches are normative and have their roots in (and limit themselves to) the traditional corporate worldview, to life that is based on rational inquiry and argument: legitimising existence, portraying image, enhancing reputation, discharging contractual responsibility, and/or managing/directing perception of stakeholders, and - most importantly - making economic success (Al-Attas, 1993; Dusuki, 2008; Hasan, 2002; Lutz, 2002).

For example, Banerjee (2001) found that corporate environmentalism follows the economic bottom line. Environmental initiatives were evaluated by a sample of US managers, according to the benefits to the firm (e.g. reduction in waste, cost savings, etc.), literally as "win-win" situations rather than an external strategic move towards an ecologically sustainable development (Hart, 1997). Similarly, Milne and Gray (2013) argue that it remains unclear whether, and to what extent, TBL has made any genuine influence on business behaviour towards the transition to an ecologically sustainable society, while its contribution to sustainability is drawing mainly upon a business "win-win" case. Their analysis suggests that the use of TBL is "a metaphor ... [and] a rhetorical diversion", which is "very unlikely to be a sufficient condition for sustainability, and indeed may lead to greater levels of un-sustainability" (p. 14). This has led to some businesses attempting to "greenwash" the public through rhetoric and relabelling (Catasús et al., 1997), through false advertising claims about environmental attributes of their investments and products/services (Entine, 1995; Rosen, 1995).

With such corporate ER approaches in place for more than two decades, a wide range of growing and severe environmental crises are now continue to erupt (e.g. greenhouse gas emissions, unbridled ecological devaluation, water scarcity, air/water pollution, land degradation, soil depletion, biodiversity loss, an eroded ozone layer, etc.), threatening not only property and commercial interests, but also life on Earth (Balali et al., 2009; Beck, 1992, 1999; Farman, 1990; Pretty, 1990; Schneider, 1990; Stern, 2006; Wilkinson and Woodin, 1990). One conclusion to draw from this fact is that such corporate environmental approaches have been less sufficient in changing attitudes that constitute the environmentally damaging consequences of society. Paul Hawken's The Ecology of Commerce (1992, 1993, p. xi) states "What we had done was scratch the surface of the problem, taken a few risks, put a fair amount of money where our mouths were, but, in the end, the impact 
on the environment was only marginally different than if we had done nothing at all". Thus, a need for new (complementary rather than alternative) approaches has arisen.

While corporate environmental strategies are important, human consciousness and behaviour can also play a powerful role in the transition towards an ecologically sustainable society (McFerran et al., 2010). ${ }^{2}$ For example, a progressive tax on carbon emission per ton would not (on its own) achieve major reductions in $\mathrm{CO}_{2}$ output. Religions can form a powerful (complementary) influence on the values, attitudes, and behaviour of individuals, defining their place in the natural environment, including how they should act towards its all elements (living and non-living). During recent decades, an environmental movement encompassing the role of religions (sometimes called spiritual ecology) has grown exponentially. ${ }^{3}$

This study agrees that in Islam, the ER concept is grounded on the belief that the human being is a vicegerent, steward, representative, and/or agent (khalifa) of God on the earth, as Adam was described by God to the Angels, "Lo! I am about to place a viceroy on earth" (Qur'an 2:30). All elements, species, habitats, and ecosystems are part of the universe created by God and made it subject to the human being (His vicegerent). This meaning was echoed, for example, in Chapter 16 (An-Nahl, in English: "Bees"):

\begin{abstract}
"And cattle He has created for you (men): from them ye derive warmth, and numerous benefits, and of their (meat) ye eat (5) ... And (He has created) horses, mules, and donkeys, for you to ride and use for show (8) ... It is He Who sends down rain from the sky: from it ye drink, and out of it (grows) the vegetation on which ye feed your cattle (10) With it He produces for you corn, olives, date-palms, grapes, and every kind of fruit: verily in this is a Sign for those who give thought (11) He has made subject to you the Night and the Day; the Sun and the Moon; and the Stars are in subjection by His Command ... (12) ... It is He Who has made the sea subject, that ye may eat thereof flesh that is fresh and tender, and that ye may extract therefrom ornaments to wear; and thou seest the ships therein that plough the waves, that ye may seek (thus) of the bounty of Allah and that ye may be grateful (14)."
\end{abstract}

Muslims serve their God's will by protecting and preserving God's creatures, who are not merely objects but are believed to have a spirit and goals of their own (Jusoff and Abu Samah, 2011). Accordingly, respecting and obeying the needs of the environment and all its components is an obligation of every Muslim who has submitted him/herself to the creator and the owner. This Islamic view of environmentalism offers a

\footnotetext{
${ }^{2}$ Individuals release almost $33 \%$ of the chemicals that form smog. They are also responsible for nearly $15 \%$ of mercury found in domestic wastewater. Motor vehicles, consumer products, and other small, non-industrial sources now constitute $76 \%$ of all air toxins. They also generate approximately $33 \%$ of US greenhouse emissions, and $33 \%$ of energy is consumed by households (Babcock, 2009a, 2009c).

${ }^{3}$ The Forum on Religion and Ecology (FORE) http://fore.yale.edu/about-us/ arose out of the initial dialogue in the mid1990s on the relationship between religions and nature, and currently serves as the largest platform of its kind.
} 
complementary way to combat the irresponsible behaviours and attitudes towards the environment, as opposed to the corporate view. According to the Qur'an (30:41) "Mischief has appeared on land and sea because of (the meed) that the hands of men have earned ...", and the only way to initiate change is in an individual's soul, intention, attitude, and action: “... Truly God will not change the condition of a people until they change the condition of their own souls ...” (Qur'an 13:11).

In the corporate view of ER, accountability is usually restricted to a company's stakeholders, all of whom are different and have different needs, thus making it difficult to be achieved (Abdallah and Murtuza, 2005; Lloyd et al., 2007; Wettstein, 2012). In contrast, the Islamic view is much broader and transcends the human realm, attributing accountability first and foremost to Almighty God, as the Qur'an states (99: 6-8):

"On that Day will men proceed in companies sorted out, to be shown the Deeds that they (had done). Then shall anyone who has done an atom's weight of good, see it! And anyone who has done an atom's weight of evil, shall see it."

This form of spiritual accountability envisages God providing human beings with various resources and blessings for their benefit and serving God's Will. In Islam, on the Day of Resurrection each person shall have to give an account of how he used them. Thus, such accountability is a relationship between human beings and their God. This kind of accountability is a wider concept as it implies a Muslim's accountability in all aspects of life, be it personal or business, and in his or her dealings with others also (Maali et al., 2006; Roughton, 2007). Hence, Muslims attempt to balance worldly gains and spiritual rewards.

At another level, the "hypothetical" social contract notion in the corporate ER worldview requires continuous renegotiation as a community's preferences change overtime (Brown et al., 2010; Donaldson and Dunfee, 1994). This proves the relative and transitional nature of ER. On the contrary, in Islam there is a similar (although not identical), but "theological" contract between God and Muslims, where Muslims promise to spend their life and property according to God's Will in return for the promise of a paradisiacal life in this world and the hereafter (Abeng, 1997). The first Islamic Republic was established on such a contract between God and his believers, administered by the prophet Mohammed and maintained through living in peace and happiness without harming society, environment, or people, and without fear of being harmed by others, as echoed in the following exemplary verses: 
"O Prophet, when the believing women come to you pledging to you that they will not associate anything with Allah, nor will they steal, nor will they commit unlawful sexual intercourse, nor will they kill their children, nor will they bring forth a slander they have invented themselves, nor will they disobey you in what is right - then accept their pledge and ask forgiveness for them of Allah. Indeed, Allah is Forgiving and Merciful.” (Qur'an 60:12)

"But those who break the covenant of Allah after contracting it and sever that which Allah has ordered to be joined and spread corruption on earth - for them is the curse, and they will have the worst home." (Qur'an 13:25)

In Islam, determination of the beneficial and the harmful is not left to one's free reasoning; Shari'ah law offers ethical guidance for people and firms on these matters. Prophet Mohammed was quoted as saying "There should be neither harming nor reciprocating harm". Islamic scholars (e.g. Sheikh al-Albāni and Ibn Taymiyyah) have used this saying and extracted an important principle in Shari'ah law that "Warding off corruption/evil takes precedence over bringing benefits". This principle has many applications in Islam. For example, the Qur'an prohibits alcoholic drinks because of associated evils (e.g. health risks), even though there are some benefits. In addition, harm for a specific (person or group) is tolerated to avoid general harm (to the masses), and preventing public harm takes precedence over private harm. However, while traditional corporate legitimacy indicates that firms should protect the environment as part of looking after their interests (a win-win case), the ethical Islamic legitimacy prioritises the environment over other things and emphasises public interests over individual interests. As a recent example of this, the Saudi government has paid out $\$ 35.5$ billion to the owners of properties that have been expropriated to make room for the expansion and modernization of the Grand Mosque in Makkah, thus better serving over 6 million pilgrims (human beings - the centre of the natural environment) every year. Accordingly, individuals are expected to protect and maintain the environment, even if doing so will affect their specific interests. This ensures that they maintain their contract with God and fulfil their religious duties (Dusuki, 2008).

The corporate viewpoint of ER creates a dilemma for individuals, companies, and communities; there are no absolute principles of ethical or moral code to guide ER as it is mainly based on the bottom line of achieving economic success. This creates a need to develop a complementary, morally driven perspective to underpin the ER concept in both individual and business daily life, especially in substantively influenced religious communities. This approach should be seen as the first link in the ethical responsibility chain, having a number of consequences on family responsibility, corporate ER and, in turn, societal responsibility. This study argues that the grounding for such an approach is deeply rooted in religions and their powerful influence on individuals' behaviour and actions. With this in mind, given the lack of ER research informed by analysis of 
divine texts, the present study attempts to cover an apparent gap in the literature with an application of the Islamic religion's divine book - the Qur'an. The authors pose the following three research questions:

$\mathrm{RQ}_{1} \quad$ To what extent is ER promoted in the verses of the Qur'an?

$\mathrm{RQ}_{2} \quad$ What types of ER themes/elements are contained in the Qur'an?

$\mathrm{RQ}_{3} \quad$ What are the implications of Qur'anic ethics of ER for business practice?

\section{Research Design}

According to Islam, the Qur'an is the last revealed message of God to all humanity through Prophet Mohammed: "We did not send you (O prophet,) but to the entire mankind" (Qur'an 34:28). In Islam, the Qur'an serves not only as a primary source of Muslim faith and religious practice, but importantly also as complete divine guidance for all life matters concerning human beings: "And We have revealed the Book to you which has clear explanation of everything, and a guidance, mercy and good news for those who submit" (Qur'an 16:89). As a comprehensive guiding principle for Muslims, the Qur'an states: 'Indeed, Allah orders justice and kindness and giving to relatives and forbids shameful acts and evil deeds and transgression. He admonishes you that perhaps you will be reminded" (Qur'an 16:90). With this in mind, from an Islamic perspective, the Qur'an is seen as a useful and rich piece of literature to be examined, looking for how and to what extent the ER concept (as a matter of concern to human beings) has been contained and explained to all human beings. To this end, a two-phase content analysis-based study was carried out.

Content analysis is "an empirically grounded method" that is "exploratory in process, and predictive or inferential in intent" (Krippendorff, 2004, p. xvii), yielding replicable and valid inferences from all kinds of texts "by objectively and systemically identifying specified characteristics of messages" (Holsti, 1969, p. 14). In content analysis-based research, two distinct approaches of the content analysis are often utilised: quantitative (based on a quantification of the message) and qualitative (based on a thematic interpretation of the message) (Krippendorf, 2004). Given this study's research questions, both quantitative and qualitative content analysis approaches were applied to the Qur'anic text, aimed at analysing the volume and meaning of the verses and understanding them within the context of Islamic ethics for ER. 
There are 6,236 verses in the Qur'an, contained in 114 chapters, divided into 30 roughly equal parts. The text is written in Arabic, in which it was revealed. Muslims believe that the Qur'an is preserved and protected by God from change and error: "Indeed, it is We who sent down the Quran and indeed, We will be it's guardian". (Qur'an 15:9). Thus, any non-Arabic Qur'anic text is neither a Qur'an nor a translation of the Qur'anic text, but rather is a translation of the meaning of the Qur'anic verses based on the context in which they were revealed. In Islam, the Qur'an was not revealed all at once to the prophet Mohammed, but gradually (throughout 23 years of Mohammed's prophethood in Makkah and Madinah) according to events and circumstances at that time, and to gradually establish the rulings for faith and life matters among Muslims: "And (it is) a Quran which We have divided into parts, in order that you might recite it to men at intervals. And We have revealed it by stages" (Quran 17:106).

The first phase of the empirical study began with a question: "What does the Qur'an contain and explain about the environment?" To address this question, an Arabic-authenticated interpretation of the Qur'an (AlSabouny, 1978) was initially chosen ${ }^{4}$. This interpretation, along with the Qur'anic text, were carefully read through in their entirety by the first two authors (Muslims and Arabic native speakers), aiming at identifying all Qur'anic verses containing references to human interaction with the environment and its elements. This process was not aiming at just counting verses that contain certain (environmentally related) words. Rather, every verse was carefully read in light of its context and reasons of revelation, thus resulting in many verses not being taken into account. For example, the Qur'anic verse 47:15 makes reference to a number of resources (i.e. rivers and plants) but in a description of the paradise for those who are God-fearing. Similarly, the Qur'anic verses 41:47 and 43:60 mention resources such as fruits and earth but in the context of God's knowledge and power. This process resulted in a number of differences $(<5 \%)$ that were discussed, clarified,

\footnotetext{
${ }^{4}$ It is believed by many Muslims that there is no singular (official) interpretation for the Qur'anic text. These differences in the interpretation are due to the richness of the Qur'anic text; language often tends to be symbolic, thus carrying various social and cultural meanings that can change with different schools of thoughts from different socio-cultural backgrounds (Islamic Research Foundation International, http://www.irfi.org). In this sense, interpretations of the Qur'an can be seen as synonyms, rather than antonyms, of the same text. With this in mind, the authors have chosen this Qur'anic interpretation for a number of reasons: (i) this interpretation is written by one of the key scholars of Qur'anic interpretations in recent times; (ii) the author of this Qur'anic interpretation was chosen by the Dubai International Holy Qur'an Award as the Islamic Character of 2007 for his publications, with special reference to the Qur'an interpretation; (iii) this interpretation is written in plain Arabic language, so easy to understand by non-experts; (iv) most importantly, this interpretation is informed by, and based on, other (relatively old) authenticated interpretations of highly respected scholars, by Islamic institutions worldwide, in this area of Islamic studies such as Al-Tabari, and Ibn Kathir; and (v) for every single verse, the author discusses meanings, the context, and reasons for revelations.
} 
and agreed with supporting evidence from other available interpretations and the relevant literature. As a result, 675 verses have been identified as verses with environmental content.

Another question was then posed: "What are the common themes of ER among the identified (675) Qur'anic verses?" A review of environmental studies revealed that environmental content is commonly categorised across a wide range of themes, such as environmental policy, energy, water, raw materials, waste and landfill, sustainability and climate change, emissions and pollution, land use/biodiversity, pollution control, waste and recycle policy, and environment protection (Aribi and Gao, 2012; Belal et al., 2015; Brammer et al., 2007; Farook et al., 2011; Gray et al., 1995a, 1995b; Haniffa, 2002; Kamla, 2007; Maali et al., 2006). However, these studies were more concerned with the impacts of companies' operation on the environment than making a reference to the categories/themes of the environmental areas. In Islam, while the Qur'an is the word of the creator of the universe to human beings, Qur'anic verses with environmental content were found to encourage reasonable use of the environment ${ }^{5}$, which requires a high degree of respect towards granted environmental resources. Accordingly, it was found useful to use natural resources such as human beings, animals, water, plants, etc., as environmental themes by which to categorise the identified (675) verses.

A checklist of environmental themes was developed and then piloted/tested by five academic experts in the research area of environmental responsibility, with an established record of high quality publications on this subject. Two of these academic experts were Muslim, one of whom was a native Arabic speaker. The final checklist was refined and covered seven environmental themes: human beings ${ }^{6}$, animals, plants, land, water, air, and other natural resources (see Table 1). To ensure comprehensiveness, the first two authors again read through all identified verses (675) against the seven identified themes. The data analysis was then carried out over two stages completed by the first author, and double-checked by the second author. Firstly, in order to

\footnotetext{
${ }^{5}$ The Qur'an (7: 31) states: “And eat and drink but waste not by extravagance, certainly He (God) likes not Al-Musrifun (those who waste by extravagance)". Accordingly, a reasonable use refers to a rational and fair use of an environmental resource (e.g. water) in a manner that is for a suitable and beneficial purpose, and that does not cause harmful results, thus not affecting the rights of others in using such a resource.

${ }^{6}$ According to the Oxford English Dictionary, environment is "the surroundings or conditions in which a person, animal, plant lives or operates" (http://www.oed.com) From an ecological perspective, this definition should include the notion of the relationship between the environment and its components (i.e. living and non-living objects that influence, and in turn are influenced by, surroundings) (Barrow, 2005; Park, 2001; Smithson et al., 2008). As ecologists and environmentalists are concerned with both biotic (living) and abiotic (non-living) components, environment may be seen as a community (i.e. ecosystem) in which organisms interact with their physical surroundings (Smithson et al., 2008). Such a view considers the human being part of the environment and a key environmental resource, which is consistent with the Qur'anic environmental perspective, yet contradicts the managerial view considering human beings and all their protection practices to belong to social ethics rather than environmental ones. Thus, this study adopts the ecological and environmental perspective regarding the human being as part (and the centre) of the environment.
} 
count verses covering each environmental theme, a score of 1 or 0 was used for each of the 675 verses against each of the seven environmental themes. This was based on the relevance of each verse and whether it referred to any of the seven themes (1) or not (0). It was possible to find verses referring to more than one theme; such verses were counted as per environmental themes covered. An un-weighted indexing procedure was used to avoid possible bias in scoring. Secondly, as noted earlier, given that the human being is the centre of the environment, it was found useful to categorise identified verses under each theme based on the interaction with the human being. Thus, verses in each of the seven themes were categorised into three main groups: verses referring to the usage of the resource by the human being; verses referring to the care of the resource by the human being; or both. Results of the empirical study are outlined in the following section. 
Table 1 Environmental responsibility themes

\begin{tabular}{|c|c|c|c|}
\hline Themes & Definition & Academic References & Qur'anic References \\
\hline Human Beings & $\begin{array}{l}\text { Do not abuse human } \\
\text { beings; Protection of } \\
\text { human beings from the } \\
\text { harmful impact of external } \\
\text { factors such as chemical } \\
\text { products and wastes. }\end{array}$ & $\begin{array}{l}\text { Haniffa and Hudaib 2007; } \\
\text { Othman et al., 2009; Ten } \\
\text { principles of the UN Global } \\
\text { Compact; Farook et al., 2011; } \\
\text { Bagader et al., 1994; Brammer et } \\
\text { al., 2007; Zubairu et al., 2011. }\end{array}$ & $\begin{array}{l}\text { Kill not one another ... (Qur'an 4:29) } \\
\text { Verily we have honoured the children of Adam. We carry them on the land and } \\
\text { the sea, and have made provision of good things for them, and have preferred } \\
\text { them above many of those whom We created with a marked preferment (Qur'an } \\
\text { 17:70) }\end{array}$ \\
\hline Animals & $\begin{array}{l}\text { Do not harm or abuse them; } \\
\text { overconsumption, etc. }\end{array}$ & $\begin{array}{l}\text { Bagader et al., 1994; Brammer et } \\
\text { al., } 2007 .\end{array}$ & $\begin{array}{l}\text { O ye who believe! Kill no wild game while ye are on the pilgrimage. Whoso of } \\
\text { you killeth it of set purpose he shall pay its forfeit in the equivalent of that which } \\
\text { he hath killed, of domestic animals, the judge to be two men among you known } \\
\text { for justice, (the forfeit) to be brought as an offering to the Ka'bah; or, for } \\
\text { expiation, he shall feed poor persons, or the equivalent thereof in fasting, that he } \\
\text { may taste the evil consequences of his deed. Allah forgiveth whatever (of this } \\
\text { kind) may have happened in the past, but whoso relapseth, Allah will take } \\
\text { retribution from him. Allah is Mighty, Able to Requite (the wrong) (Qur'an } \\
5: 95 \text { ) }\end{array}$ \\
\hline Plants & $\begin{array}{l}\text { Protecting plants, abuse of } \\
\text { plants; overconsumption, } \\
\text { etc. }\end{array}$ & $\begin{array}{l}\text { Bagader et al., 1994; Brammer et } \\
\text { al., } 2007 .\end{array}$ & $\begin{array}{l}\text { And the earth have We spread out, and have flung firm hills therein, and have } \\
\text { caused of every lovely kind to grow thereon, (Qur'an 50:7) } \\
\text { Wherein are fruit and sheathed palm-trees, Husked grain and scented herb } \\
\text { (Qur'an 55:11-12) }\end{array}$ \\
\hline Land & $\begin{array}{l}\text { Protecting land and not } \\
\text { abusing it; soil erosion; } \\
\text { ozone depletion, etc. }\end{array}$ & $\begin{array}{l}\text { Bagader et al., 1994; Brammer et } \\
\text { al., 2007; Kamla, 2007. }\end{array}$ & $\begin{array}{l}\text { Those who break the covenant of Allah after ratifying it, and sever that which } \\
\text { Allah ordered to be joined, and (who) make mischief in the earth: Those are they } \\
\text { who are the losers (Qur'an 2:27) } \\
\text { And if the Truth had followed their desires, verily the heavens and the earth and } \\
\text { whosoever is therein had been corrupted. Nay, We have brought them their } \\
\text { Reminder, but from their Reminder they now turn away (Qur'an 23:71) } \\
\text { Corruption doth appear on land and sea because of (the evil) which men's hands } \\
\text { have done, that He may make them taste a part of that which they have done, in } \\
\text { order that they may return (Qur'an 30:41) } \\
\text { Would ye then, if ye were given the command, work corruption in the land and } \\
\text { sever your ties of kinship? (Qur'an } 47: 22 \text { ) } \\
\text { Who (all) were rebellious (to Allah) in these lands, And multiplied iniquity } \\
\text { therein? (Qur'an 89:11-12) }\end{array}$ \\
\hline
\end{tabular}




\begin{tabular}{|l|l|l|l|}
\hline Water & $\begin{array}{l}\text { Do not pollute water or } \\
\text { misuse it; wastewater } \\
\text { treatment; } \\
\text { overconsumption. }\end{array}$ & $\begin{array}{l}\text { Bagader et al., 1994; Brammer et } \\
\text { al., 2007; Kamla, 2007. }\end{array}$ & $\begin{array}{l}\text { And we send down from the sky water in measure, and We give it settle in the } \\
\text { earth, and lo! We are Able to withdraw it (Qur'an 23:18) } \\
\text { Is not He (best) Who created the heavens and the earth, and sendeth down for } \\
\text { you water from the sky wherewith We cause to spring forth joyous orchards, } \\
\text { whose trees it never hath been yours to cause to grow. Is there any God beside } \\
\text { Allah? Nay, but thy are folk who ascribe equals (unto Him)! Is not He (best) } \\
\text { Who answereth the wronged one when he crieth unto Him and removeth the } \\
\text { evil, and hath made you viceroys of the earth? Is there any God beside Allah? } \\
\text { Little do they reflect! (Qur'an 27:60-61) }\end{array}$ \\
\hline Air & $\begin{array}{l}\text { Do not pollute air; } \mathrm{CO}_{2} \text { and } \\
\text { coal emissions; climate } \\
\text { change, etc. }\end{array}$ & $\begin{array}{l}\text { Bagader et al., 1994; Brammer et } \\
\text { al., 2007. }\end{array}$ & $\begin{array}{l}\text { Allah is He Who sendeth the winds so that they raise clouds, and spreadeth them } \\
\text { along the sky as pleaseth Him, and causeth them to break and thou seest the rain } \\
\text { downpouring from within them. And when He maketh it to fall on whom He will } \\
\text { of His bondmen, lo! they rejoice (Qur'an30:48) } \\
\text { See ye not how Allah hath made serviceable unto you whatsoever is in the skies } \\
\text { and whatsoever is in the earth and hath loaded you with His favours both without } \\
\text { and within? Yet of mankind is he who disputeth concerning Allah, without } \\
\text { knowledge or guidance or a scripture giving light (Qur'an 31:20) }\end{array}$ \\
\hline $\begin{array}{l}\text { Other Natural } \\
\text { Resources }\end{array}$ & $\begin{array}{l}\text { Protect them and do not } \\
\text { harm or abuse them; } \\
\text { hazardous waste; } \\
\text { overconsumption. }\end{array}$ & $\begin{array}{l}\text { Bagader et al., 1994; Brammer et } \\
\text { al., 2007; Kamla, 2007; Zubairu et } \\
\text { al., 2011; Belal et al., 2015. }\end{array}$ & $\begin{array}{l}\text { And all things We have created by pairs, that haply ye may reflect (Qur'an } \\
51: 49) \\
\text { Lo! We have created everything by measure (Qur'an 54:49) }\end{array}$ \\
\hline
\end{tabular}




\section{Empirical Results}

\section{Overall Descriptive}

Through the Qur'anic message, the earth is mentioned more than 400 times, while the sky and similar entities are mentioned approximately 300 times (Jusoff and Abu Samah, 2011). Many chapter headings in the Qur'an are named after natural resources and phenomena. This is to emphasise their importance, inviting human beings to think of them as expressions of the divine creativity, and thus, holy in their very substance: "Thunder", "The Star", "The Moon", "The Sun”, "Dawn", "Morning Hours", "The Sand Dunes", "Smoke", "The Winnowing Winds", "Iron”, “The Ants", "The Bees”, “The Spider", "Cattle”, “The Elephant”, and "The Fig”. As Bagader et al. (1994) indicated, the Qur'an highlights the fact that everything was created by God, who has made it subject to the human being: "And He has subjected to you whatever is in the heavens and whatever is on the earth - all from Him. Indeed in that are signs for a people who give thought" (45:13). This reflects that humans accepted the earth in trust on behalf of $\mathrm{God}^{7}$, and are under an obligatory responsibility to protect and conserve all natural resources, avoiding exploitation, distraction, abuse, pollution, and to protect it from becoming scarce (Bagader et al., 1994; Deuraseh, 2009). Failing to do so neglects one's accountability in maintaining the balance God created, and in turn, neglects one's accountability and responsibility towards protecting other creatures (Abdallah and Murtuza, 2005).

As Table 2 shows, there are 675 verses (11\%) in 84 chapters $(74 \%)$ over the whole 30 parts showing evidence for ER towards human and natural resources. Of these, $525(78 \%)$ verses show moral responsibility for respecting and protecting human beings, $106(16 \%)$ are associated with using and looking after the natural resources of water, $24(4 \%)$ for using and protecting the air, $166(25 \%)$ relate to the land as a natural resource, $108(16 \%)$ referring to plants, $102(15 \%)$ revealing the importance of the proper treatment of animals, and 248 (37\%) relating to the other natural resources. Table 2 also represents the human's (khalifa) role of utilising and protecting God's creatures.

The rest of the empirical results section outlines how the Qur'an urges human beings to care for, protect, and adequately use different elements of the natural environment across the seven environmental themes. This will be followed by implications for business practice in a separate section.

\footnotetext{
${ }^{7}$ God says, "Verily, We did offer the trust to the heavens and the earth, and the mountains: but they refused to bear it. Yet man took it up — for, verily, he has always been prone to tyranny and foolishness" (Qur'an 33:72).
} 
Table 2 Descriptive analysis of Qur'anic environmental responsibility themes

\begin{tabular}{lrrrrrrr}
\hline \multicolumn{1}{c}{ Items } & \multirow{2}{*}{ Chapters (\%) } & \multirow{2}{*}{ Verses } & \multirow{2}{*}{$\%$} & \multirow{2}{*}{ of 675} & \multicolumn{3}{c}{ Human $($ khalifa $)$ roles } \\
The whole Qur'an & $114(100)$ & 6,236 & 100 & N/A & N/A & Carer $(\%)$ & Both (\%) \\
Human beings & $75(66)$ & 525 & 8 & 78 & $173(33)$ & $186(35)$ & $166(32)$ \\
Water & $49(43)$ & 106 & 2 & 16 & $93(88)$ & $2(2)$ & $11(10)$ \\
Air & $18(16)$ & 24 & 0.4 & 4 & $18(75)$ & $6(25)$ & $0(0)$ \\
Land & $52(46)$ & 166 & 3 & 25 & $112(67)$ & $33(20)$ & $21(13)$ \\
Plants & $44(39)$ & 108 & 2 & 16 & $85(78.5)$ & $4(4)$ & $19(17.5)$ \\
Animals & $40(35)$ & 102 & 2 & 15 & $73(71.5)$ & $7(7)$ & $22(21.5)$ \\
Other resources & $67(59)$ & 248 & 4 & 37 & $176(71)$ & $26(10)$ & $46(19)$ \\
\hline Total & $84(74)$ & 675 & 11 & 100 & N/A & N/A & N/A \\
\hline
\end{tabular}

\section{Human Beings}

Human beings as an element of the environment occupied a significant share of the Qur'an, mentioned in 525 verses (33\% as a resource, $35 \%$ for protecting, and 32\% for both) over 75 chapters. Humans are part of the universe whose elements supplement one another, but a distinctive part as representatives who have intellect and who obey God's commands. They are preferred by God, causing all other elements of the environment to honour them and be at their service (Kader et al., 1983): "Verily we have honoured the children of Adam. We carry them on the land and the sea, and have made provision of good things for them, and have preferred them above many of those whom We created with a marked preferment" (Qur'an 17:70).

In Islam, human life is highly regarded, respected, and protected (Zinkin, 2007; Deuraseh, 2009). Therefore, God strictly prohibits individuals to terminate anyone's life unjustly, to kill one another, or to commit suicide no matter what reason one has; human beings are honoured as a "symbol of divinity" (Abou El-Fadl 2003): “... whosoever killeth a human being for other than manslaughter or corruption in the earth, it shall be as if he had killed all human beings, and whoso saveth the life of one, it shall be as if he had saved the life of all human beings ..." (Qur'an 5:32). Islam prohibits exchanging money for certain products and activities (e.g. alcohol, cigarettes, and gambling) that can cause considerable harm to human being's health and wellbeing: "They question thee about strong drink (wine) and games of chance (gambling). Say: In both is great sin, and (some) utility for men; but the sin of them is greater than their usefulness..." (Qur'an 2:219).

Human beings are ordered to protect each other as a resource of the natural world. The Qur'an calls for the wealthy, powerful, and the strong to take care of, protect, and help the weak and the needy, even if they are not Muslims. For example, in the context of protecting orphans' rights and helping them, God says: "Give unto 
orphans their wealth. Exchange not the good for the bad (in your management thereof) nor absorb their wealth into your own wealth. Lo! that would be a great sin" (Qur'an 4:2). Further, the Qur'an equalises women and men in terms of duties, responsibilities, and rights. However, men are ordered to take care of and protect women and children: "Men are in charge of women, because Allah hath made the one of them to excel the other, and because they spend of their property. So good women are the obedient, guarding in secret that which Allah hath guarded ..." (Qur'an 4:34).

\section{Water}

In Islam, the Qur'an and the Sunnah stipulate that water is the basic necessity of life; therefore they place a number of obligations and responsibilities upon Muslims to conserve and use the existing water supplies in the best possible rational ways. Water, as a key natural resource, is mentioned in 106 verses across 49 chapters throughout the Qur'an: $88 \%$ reviewed usage and benefits of the water, 2\% discussed care of the resource, and $10 \%$ commented on both.

In the Qur'an, God states the different benefits and uses of water. Water is mentioned as the basis and origin of life: “... and we made every living thing of water ..." (Qur'an, 21:30). All creatures, plants, animals, and humans essentially depend on water for their survival and continuous existence: "O mankind! ... And thou (Muhammad) seest the earth barren, but when We send down water thereon, it doth thrill and swell and put forth every lovely kind (of growth)" (Qur'an 22:5). Human being is also reminded to appreciate water's value, and warned that no-one else can provide them with a substitute, nor can they find an alternative if the water should vanish (Qur'an 56:68-70).

\section{Air}

Air is extremely important for the continuation and preservation of life; nearly all earthly creatures are dependent on the air they breathe. Air is mentioned in 24 verses across 18 chapters throughout the Qur'an: 75\% commented on usage of air, while 25\% discussed care of this resource. The Qur'an discloses other duties for wind in benefitting humans and facilitating their lives (Bagader et al. 1994). As expressed by Kader et al. (1983), wind plays an important role in pollination and in moving clouds that cause rain. God says, "And We send the winds fertilising, and cause water to descend from the sky, and give it you to drink. It is not ye who are the holders of the store thereof" (Qur'an 15:22). 
Serving biological and social functions, air is an essential aspect of the conservation of life, which is one of the fundamental objectives of Islamic law. For Muslims, whatever is crucial to achieve this imperative responsibility is obligatory. Any activity, therefore, that pollutes and damages its function is an effort to thwart and obstruct God's wisdom towards His creation (Qur'an 40:64). This must be considered as an obstruction of some aspects of the human's role in the development of this world. The ozone "hole" over the Antarctica, for example, is a phenomenon where the stratosphere is thinned out and this is caused by refrigerants (e.g. chlorofluorocarbons, halons, and freons). In Islam, God mentions the atmosphere in an embracing way: "And we have made the sky a roof withheld (from them). Yet they turn away from its portents" (Qur'an 21:32). Thus, God has covered the earth with atmosphere and individuals/groups have burned it away. In Islam, organisations as a group of individuals, (especially in high environmental impact sectors such as food retailers, general retailers, personal goods, and general industry) are highly expected to restore the ozone layer by having global diligence and commitment to neutralising toxic gases and radiation.

\section{Land}

Land is also important for continuity of life on Earth. God mentions it several times in the Qur'an, clarifying its benefit and usefulness. Land, as one of the natural resources, is mentioned in 166 verses across 52 chapters throughout the Qur'an: 67\% talked about usage of the land/soil resource, 20\% discussed care of the resource, and $13 \%$ commented on both. God mentions the value of land in terms of the minerals that humans, as well as plant and animals, derive from it; it is a source of food for these beings and produces vegetation that also grows on its mountains (Bagader et al., 1994). God also made land a home for all creatures with vast open space (Qur'an 71:17-20). Further, God made the soil fertile to grow crops and vegetables upon which these beings feed. He also made mountains a source of water and an aid in agriculture as they hold rain. In this statement, God says, "Have We not made the earth a receptacle, Both for the living and the dead, And placed therein high mountains and given you to drink sweet water therein?" (Qur'an 77:25-27). The land/earth is introduced as "a mother" of human beings. The prophet Mohammed was quoted as saying: "Preserve the earth because it is your mother". In this context, God states: "He brought you forth from the earth and hath made you husband it. So ask forgiveness of Him and turn unto Him repentant"' (Qur'an 11:61).

Accordingly, it is clear that God mentions these ethical rules of using and benefiting from land and soil to make human beings realise how precious this resource is, and that they need to show gratitude to God by 
protecting it from degradation, pollution, and erosion by wind and flood. Humans are obliged to enhance the productivity of land, to preserve its fertility and avoid destruction of life on Earth; to protect the soil, improve abandoned land, or otherwise deny God's favours and earn punishment by mistreating this non-renewable resource (Bagader et al., 1994; Kula, 2001).

\section{Plants}

Plants are a living resource with massive benefits as a source of survival for human beings and animals. For example, they provide a basic source of food. In the Qur'an, God states, "Let man consider his food: How We pour water in showers, Then split the earth in clefts, And cause the grain to grow therein, And grapes and green fodder, And olive-trees and palm-trees, And garden-closes of thick foliage, And fruits and grasses: Provision for you and your cattle" (Qur'an 80:24-32). As an environmental resource, plants are mentioned in 108 verses across 44 chapters throughout the Quran: $78.5 \%$ talked about usage of the resource, $4 \%$ discussed care of the resource, and $17.5 \%$ commented on both. In addition, plants have various other uses, e.g. enriching and protecting land from wind and water erosion. They are also a source of oxygen alongside medicines, perfumes, oils, timber, wax, fuel, and energy (fire) (Bagader et al., 1994). God says, "Have ye observed the fire which ye strike out; Was it ye who made the tree thereof to grow, or were We the grower? We, even We, appointed it a memorial and a comfort for the dwellers in the wilderness" (Qur'an 56:71-73).

\section{Animals}

The compassion and mercy of Islam not only encompasses humans, but also extends to all creatures including animals. Animals are awarded special recognition and regard in the Qur'an, as God says, "There is not an animal in the earth, nor a flying creature flying on two wings, but they are peoples like unto you" (Qur'an 6:38). The "Animal", as one of the environmental resources, is mentioned in 102 verses across 40 chapters throughout the Qur'an: 71.5\% talked about usage of the animal resource, 7\% discussed care (proper treatment) of the resource, and $21.5 \%$ commented on both. Animals are of great benefit to human being: they provide humans with hair, leather, wool, they supply medicine, perfumes, and are often a mode of transportation (Bagader et al., 1994; Qur'an 16:5-8). Animals (with plants) are mentioned in the Qur'an as beautiful creatures, providing joy, pleasure, enjoyment, and the peace of mind required for human being's proper functioning and performance (Bagader et al., 1994; Kader et al., 1983). For example, God says, "And wherein is beauty for you, when ye bring them home, and when ye take them out to pasture" (Qur'an 16:6). 
Another function of animals is the worshipping of God, bowing down to him as forced by their nature to do so (Qur'an 22:18). As human being is not sole in its worship of God and shares this with other creatures (despite differences in their ways of worshipping their creator), all living things deserve respect, protection, and care (Bagader et al., 1994; Kula, 2001). Otherwise, the destruction of nature by willful human behaviour will result in these irreplaceable, unique resources being lost forever (Bagader et al., 1994; Kula, 2001); "Destruction hath appeared by land and by sea on account of what men's hands have wrought, that it might make them taste somewhat of the fruit of their doings, that haply they might turn to God" (Qur'an 16:40).

Undoubtedly, animals have been mis(used) in medical research and development since $300 \mathrm{BC}$ and have played an important role throughout the history of the life sciences. In the 20th century, animal-based research led to many medical advances and treatments, including insulin for the treatment of diabetes (Novo Nordisk, 2008). In the pharmaceutical and biotechnology industry, for example, experiments on living animals are an essential part of the discovery and development of new drugs. The use of experimental animals is, however, a source of concern for many people, animal welfare organisations, and non-governmental organisations (e.g. National Animal Rights Organisation, Lush, REACH, and Charity Pot).

Islam prohibits unkindness to animals; harming them is sufficient reason for a person to be thrown into Hell. The prophet Mohammed told his companions that God appreciated man's good work and forgave him, as he went down the well and got some water for a thirsty dog. Accordingly, the companions asked, "O Prophet of God, do we get rewarded on humane treatment of animals?" He said, "There is a reward in doing good to every living being". The prophet Mohammed described God's punishment of a women who was sent to Hell because of a cat she kept locked up, neither feeding her nor setting her free to feed herself. With regard to slaughtering animals in Islam, Muslims should slaughter the animal and not use other methods to kill them. The prophet Mohammed said, "If someone slaughter an animal let him slaughter very well, let him sharpen his knife and let the animal rest". Muslims are also instructed not to show animals when another is being slaughtered. For Eid Aldha, a special event for sacrificing animals for the sake of God, Muslims are recommended to slaughter the animal as explained above and to divide the meat into three equal pieces: one for poor people to eat as charity, one for relatives, neighbours, or friends as a gift, and one for the owner. 


\section{Other Natural Resources}

Other natural resources are made available for human use, without abuse or misuse. There are numerous verses in the Qur'an that could be cited in this respect. These other natural resources such as the sun, moon, stars, hills, day, and night, are mentioned in 248 verses, across 67 chapters: $71 \%$ talked about usage of the resource(s), $10 \%$ discussed care of the resource(s), and 19\% commented on both. In this context, God says, "Allah it is Who raised up the heavens without visible supports, then mounted the Throne, and compelled the sun and the moon to be of service, each runneth unto an appointed term; He ordereth the course; He detaileth the revelations, that haply ye may be certain of the meeting with your Lord" (Qur'an 13:2; see also, 10:67; $16: 12 ; 25: 47)$. God also says: "And we have made the sky a roof withheld (from them). Yet they turn away from its portents. And He it is Who created the night and the day, and the sun and the moon. They float, each in an orbit" (Qur'an 21:32-33; see also, 15:19; 21:79). While stars are expressed in the Qur'an as a gift from God to guide humans at night (Qur'an 6:97), the sun and moon are also articulated as means to help people measure time and calculate their years (Qur'an 10:5), and as sources of light (Qur'an 71:16).

In contrast to the above benefits of other natural resources, the human exploration and habitation of Outer Space, including the moon, may significantly impact the density, construction, and chemical structure of the moon's atmosphere. This will result in the first case of the unintended terraforming of another world. Similarly, the extensive use of technologies towards space programmes, nuclear arms race, and star wars between the Soviet Union and US have the same negative impacts on space (www.nasa.gov). The Islamic attitude towards environment and other natural resource conservation is not only based on prohibition of overexploitation but also on sustainable development (e.g. Qur'an 2:29; 6:97; 13:2; 21:16; 45:13; 55:5-9). This integration of the development and conservation of natural resources should be embedded in business activities. Additionally, businesses and corporations should be environmentally conscious, and supportive of environmental quality and pay attention to it in their own operations.

\section{Implications for Business Practice}

Environment refers to the complex of physical, chemical, and biological components affecting human and nonhuman beings (Barrow, 2005; Park, 2001; Smithson et al., 2008). The natural ecosystem, therefore, is a highly diverse and balanced system. The Qur'anic message to human beings takes a balanced environmental view: 
usage and protection (see Qur'an 15:19-21; 54:59). Both the Qur'an and the Prophetic hadith (saying and action of prophet Mohammed) cover and organize the relationship between human beings and the environment and its components. This Islamic view of environmental responsibility is quite distinct from much work and practice in corporate environmental responsibility. Findings of this study have several business implications for not only Muslim markets, but also other markets. Table 3 presents examples of business implications across the seven environmental themes and their ethical aspects, supported by examples of Qur'anic evidence. These implications with specific examples from relevant industrial sectors are discussed below.

As Table 3 demonstrates, the Qur'an considers the human being as the centre of the universe, s/he is a key part of it (i.e. an environmental resource) and it was made subject to her/him (with a responsibility to look after it). Also, prophetic teachings provide evidence for the business implications of mankind's behaviour for respecting human beings (Abdelzaher and Abdelzaher, 2015). In practice, Islamic ethical aspects define several implications for businesses in different industrial sectors, with special reference to high environmental impact sectors such as noise reduction, minimising hazardous and non-hazardous emissions/waste to the lowest possible rate, perfecting waste management, and preventing abuse of women and child labour. Thus, companies can use such ethical aspects to influence the behaviour of their individuals (e.g. board members, managers, employees, suppliers, customers) and developing more effective sustainability plans.

According to Islamic teachings, humans have no right to exploit any element of the environment: "Allah is the creator of all things, and $\mathrm{He}$ is Guardian over all things" (Qur'an 39:62). There is no doubt that an environmental crisis such as global pollution and climate change are immediate concerns, and therefore managers and business leaders should find the opportunity to develop and launch innovative efficient energy technologies that have minimal impact on the environment. Electric power, oil and gas industries can develop and produce fuel cells for power transportation, renewable energy systems, and combined cooling, heating, and power systems. This should go hand-in-hand with their managers' personal vision for protecting the natural resources and reducing the now inevitable effects of climate change.

A recent example revealing the importance of human related ethical aspects and business implications is the Rana Plaza garment factory in Savar Dhaka, which collapsed on $24^{\text {th }}$ April 2013. This case highlights the current dangerous labour conditions in a highly environmental impact industry - the garment and textiles industry. With 1,200 deaths and thousands of injuries, this recent deadly human disaster presents issues of 
labour and human rights including the abuse of women and child labour, absence of safety and working conditions, etc. In this vein, the prophet Mohammed said:

"Every one of you is a shepherd and is responsible for his flock. The leader of people is a guardian and is responsible for his subjects. A man is the guardian of his family and he is responsible for them. A woman is the guardian of her husband's home and his children and she is responsible for them. The servant of a man is a guardian of the property of his master and he is responsible for it. Surely, every one of you is a shepherd and responsible for his flock."

Accordingly, managers of leading world clothing brands using labour in other developing markets (e.g. Next, Debenhams, Walmart, M\&S, Mango, and Benetton) are encouraged to re-structure their ethical responsibility roadmap to include supply chains and sourcing management practice to investigate the fire, safety, and working conditions, and to respect the human and labour rights of their suppliers (Ali et al. 2000; Beekun and Badawi 2005; Byrne 2011; Sidani and Al Ariss 2015; Tlaiss 2015; Zinkin 2007).

Due to the rapid increase in the total human population over time, an inevitable demand on natural environmental resources and waste assimilation is required. Muslims are taught their specific role as deputies who are entrusted to protect and not exploit natural resources by behaving in a way that is revealed in the Qur'an and Hadith (Abdelzaher and Abdelzaher, 2015). For example, God says: "Eat and drink of that which Allah hath provided, and do not act corruptly, making mischief in the earth" (Qur'an 2:60; see also Qur'an 17:27). The prophet Mohammed did not encourage his companions to eat a three-course meal nor a heavy meal; he said, "The believer is not he who eats his fill while his neighbor is hungry". He also said, "Nothing is worse than a person who fills his stomach. It should be enough for the son of Adam to have a few bites to satisfy his hunger. If he wishes more, it should be: One-third for his food, one-third for his liquids, and onethird for his breath". The prophet Mohammed repaired his own shoes, sewed his clothes, and carried out all household chores. This was to encourage Muslims to reduce consumption, and reuse and repair (recycle) instead of always buying new things. Furthermore, food producers and food retailers could therefore include these teachings in their sustainable strategies. Also, consumer interest groups could embed this advice into their strategies and disseminate to members of the public also. An example for the influential role that religions can play is the role played by eco-religious bodies in Tanzania to promote green fishing against Blast fishing, by reminding individuals of Qur'anic edicts on their role as agents of God in conserving the ecosystem, avoiding overconsumption, and respecting animal rights (ARCWORLD, 2011). 
Table 3 Ethical aspects and business implications of Qur'anic environmental responsibility themes

\begin{tabular}{|c|c|c|c|}
\hline $\begin{array}{l}\text { Environmental } \\
\text { Resource(s) }\end{array}$ & Ethical Aspect(s) & $\begin{array}{l}\text { Qur'anic } \\
\text { Evidence }\end{array}$ & Business Implication Example(s) \\
\hline \multirow[t]{4}{*}{ Human Beings } & $\begin{array}{l}\text { Ability to use and benefit from } \\
\text { resources and other humans to add } \\
\text { positive values to themselves and } \\
\text { society }\end{array}$ & $\begin{array}{l}\text { Qur'an - } \\
\text { 15: } 23 \\
30: 21-22\end{array}$ & $\begin{array}{ll} & \text { Adoption long-term sustainable and responsible investment } \\
\circ & \text { Encouragement of a proper use of resources, spending, and investment in business's units } \\
\circ & \text { Efficient use resources } \\
\circ & \text { Development of a noise reduction good practice guide } \\
\text { - } & \text { Industries: Cement, Construction \& Materials, Aerospace \& Defence and Garment \& Textiles. }\end{array}$ \\
\hline & $\begin{array}{l}\text { Respect, responsible use, and } \\
\text { considerable protection to living and } \\
\text { non-living things }\end{array}$ & $\begin{array}{l}\text { Qur'an - } \\
\text { 2: } 11 \& 205 \\
5: 28-30 \\
17: 26\end{array}$ & $\begin{array}{ll}\circ & \text { Zero death/health incidents } \\
\circ & \text { Eliminate noise } \\
\circ & \text { Proper use of Fertilizers \& Pesticides } \\
\circ & \text { Set Action Plan to achieve zero hazardous and non-hazardous emissions/waste } \\
\circ & \text { Training programmes, R\&D, knowledge transfer } \\
\circ & \text { Businessperson will not be coerced into unethical practices } \\
\circ & \text { Excellence of working conditions and quality of goods and services } \\
- & \text { Industries: Oil \& Gas, Mining, Chemicals, Agricultural, and Aerospace \& Defence. }\end{array}$ \\
\hline & $\begin{array}{l}\text { Respecting divinity and others' } \\
\text { privacy }\end{array}$ & $\begin{array}{l}\text { Qur'an - } \\
\text { 17: } 31-32 \\
\text { 19: } 14 \& 32 \\
24: 3-4 \& 30\end{array}$ & $\begin{array}{ll}\circ & \text { Equal opportunity and no race discrimination among employees, suppliers, buyers, etc. } \\
\circ & \text { Respect stakeholder activism and diversity } \\
\circ & \text { Respecting human and labour rights } \\
\text { - } & \text { Industries: Garment \& Textiles, Telecom., and Health Care Equipment \& Services }\end{array}$ \\
\hline & $\circ \quad$ Achieving equality and justice & $\begin{array}{l}\text { Qur'an - } \\
4: 2-7 \\
25: 72\end{array}$ & $\begin{array}{ll}\circ & \text { Job security and staff satisfaction } \\
\circ & \text { Prevent women abuse } \\
\circ & \text { Prevent child labour } \\
- & \text { Industries: Garment \& Textiles, Banks, General Retailers, and Transportation. } \\
\end{array}$ \\
\hline \multirow[t]{5}{*}{ Water } & $\begin{array}{l}\text { Water is a condition for survival, } \\
\text { existence, growing, and cleaning } \\
\text { dirty. }\end{array}$ & $\begin{array}{l}\text { Qur'an- } \\
2: 60 \\
16: 10\end{array}$ & $\begin{array}{ll} & \text { Prioritise the usage of fresh water } \\
\circ & \text { Improve the efficiency of water usage } \\
\circ & \text { Proper use of Fertilizers \& Pesticides } \\
- & \text { Industries: Agricultural, Gas, Water \& Utilities, Chemicals, and Food Producers. }\end{array}$ \\
\hline & ○ Appreciating water's value & $\begin{array}{l}\text { Qur'an - } \\
\text { 15: } 21 \\
\text { 17: } 70 \\
\text { 23: } 22\end{array}$ & $\begin{array}{ll}\circ & \text { Reduce the cost of water usage } \\
\circ & \text { Increase the use of seawater and treated water } \\
\circ & \text { Use seas a cheaper and green mode of transportation } \\
- & \text { Industries: Travel \& Tourism, Mining and Construction \& Materials. } \\
\end{array}$ \\
\hline & $\begin{array}{l}\text { Responsibility to not abuse or } \\
\text { pollute it }\end{array}$ & $\begin{array}{l}\text { Qur'an - } \\
20: 81\end{array}$ & $\begin{array}{ll} & \text { Reduce mains water use } \\
\circ & \text { Managing the water footprint of supply chains } \\
\text { - } & \text { Industries: Travel \& Tourism, Mining, Construction \& Materials and Agricultural. }\end{array}$ \\
\hline & $\begin{array}{l}\text { Responsibility to not over-consume, } \\
\text { or spoil, or waste it. }\end{array}$ & $\begin{array}{l}\text { Qur'an - } \\
7: 31\end{array}$ & $\begin{array}{ll} & \text { Fit water saving applications to colleagues, customers, suppliers, etc. } \\
\circ & \text { Reuse and recycle water } \\
\text { - } & \text { Industries: Food Producers, Travel \& Tourism, Construction \& Materials and Beverage. }\end{array}$ \\
\hline & $\begin{array}{l}\text { Protect and conserve water for the } \\
\text { preservation of different forms of } \\
\text { life on the earth. }\end{array}$ & $\begin{array}{l}\text { Qur'an - } \\
\text { 23: } 18 \\
\text { 54: } 49\end{array}$ & $\begin{array}{ll}\circ & \text { Reduce/eliminate waste water } \\
\circ & \text { Develop water stewardship strategies with suppliers \& producers }\end{array}$ \\
\hline
\end{tabular}




\begin{tabular}{|c|c|c|c|c|}
\hline & & & & - Industries: Agricultural, Construction \& Materials and Mining. \\
\hline \multirow[t]{3}{*}{ Air } & & $\begin{array}{l}\text { Air is important for generating } \\
\text { energy, pollination, fertilising and } \\
\text { causing rains. }\end{array}$ & $\begin{array}{l}\text { Qur'an - } \\
15: 22 \\
21: 81\end{array}$ & $\begin{array}{ll} & \text { Build wind turbines to produce green energy } \\
\text { - } & \text { Industries: Electricity, Banks \& Financial Services and Travel \& Tourism }\end{array}$ \\
\hline & ○ & $\begin{array}{l}\text { Benefit from this resource without } \\
\text { abuse or polluting it. }\end{array}$ & $\begin{array}{l}\text { Qur'an - } \\
44: 38 \\
54: 49 \\
89: 12\end{array}$ & $\begin{array}{ll} & \text { Efficient and responsible use air as a mode of transportation } \\
\circ & \text { Improve and increase air vehicle space } \\
\circ & \text { Use energy produced by wind power } \\
\circ & \text { Reduce } \mathrm{SO}_{2} / \mathrm{CO}_{2} \text { emissions per square metre/£sales } \\
\circ & \text { Reduce energy consumption } \\
\circ & \text { Reduce dust which contains heavy metals like chromium, nickel, cobalt, etc. } \\
\text { - Industries: Cement, Chemicals, Automobiles \& Parts, Aerospace \& Defence Travel \& Tourism, } & \text { Telecommunication, and Media. }\end{array}$ \\
\hline & & $\begin{array}{l}\text { Conserve air for the continuation } \\
\text { and preservation of life }\end{array}$ & $\begin{array}{l}\text { Qur'an- } \\
15: 21 \\
23: 18\end{array}$ & $\begin{array}{ll}\circ & \text { Switch stores/branches to natural } \mathrm{CO}_{2} \text { refrigerant } \\
\circ & \text { Reduce road miles and increase miles per gallon } \\
\circ & 100 \% \text { elimination of ozone depletion } \\
- & \text { Industries: Chemicals, Oil \& Gas, Travel \& Tourism, Retailers, and General Industry. } \\
\end{array}$ \\
\hline \multirow[t]{3}{*}{ Land } & ○ & $\begin{array}{l}\text { Benefit from minerals, plants and } \\
\text { animals derive from land }\end{array}$ & $\begin{array}{l}\text { Qur'an - } \\
11: 6 \\
16: 15 \\
18: 7\end{array}$ & $\begin{array}{ll} & \text { Responsible land use } \\
\circ & \text { Maximise the benefits of using minerals, crops, etc. } \\
\text { - } & \text { Industries: Agricultural, Food Producers, Forestry \& Paper, Travel \& Tourism, Aerospace \& } \\
\text { Defence and Cement. }\end{array}$ \\
\hline & & $\begin{array}{l}\text { Efficient use of land and soil to } \\
\text { cultivate crops and vegetables, etc. }\end{array}$ & $\begin{array}{l}\text { Qur'an - } \\
14: 32 \\
15: 19\end{array}$ & $\begin{array}{ll}\circ & \text { Prevent, minimise, rehabilitate and offset impact to land and its resources } \\
\circ & \text { Reduce eyesores such as soil erosion, waste-rock piles, open pits, etc. } \\
\text { - } & \text { Industries: Agricultural, Forestry \& Paper, Chemicals, and Mining. }\end{array}$ \\
\hline & & $\begin{array}{l}\text { Obligation to protect all kinds of } \\
\text { land; no exploitation or } \\
\text { carelessness, etc. }\end{array}$ & $\begin{array}{l}\text { Qur'an } \\
2: 22 \\
7: 56 \\
26: 183 \\
28: 77 \\
67: 15\end{array}$ & $\begin{array}{ll} & \text { Integrate biodiversity management into management systems } \\
\circ & \text { Reduce/eliminate waste sent to landfill } \\
\circ & \text { Proper use of Fertilizers \& Pesticides } \\
\circ & \text { Set Action Plan for Biodiversity } \\
\circ & \text { Efficient use of these free lands by cultivating crops, trees, or constructing houses. } \\
\text { - } & \text { Industries: Agricultural, Forestry \& Paper, Mining, Cement, Travel \& Tourism, \& Construction. }\end{array}$ \\
\hline \multirow[t]{4}{*}{ Plants } & & $\begin{array}{l}\text { Use plants as a source of survival } \\
\text { for both mankind and animals }\end{array}$ & $\begin{array}{l}\text { Qur'an - } \\
5: 88 \\
6: 99 \\
8: 69\end{array}$ & $\begin{array}{ll} & \text { Efficient use of fruits and vegetables } \\
\circ & \text { Use natural resources instead of pesticides } \\
\circ & \text { Increase the \% of wood fibre bought from WWF Forest \& Trade } \\
\text { - } & \text { Industries: Agricultural, Forestry \& Paper, and Food \& Drug Retailers. }\end{array}$ \\
\hline & & $\begin{array}{l}\text { Source of oxygen, medicines, } \\
\text { perfumes, oils, etc. }\end{array}$ & $\begin{array}{l}\text { Qur'an - } \\
16: 11-13\end{array}$ & $\begin{array}{l}\text { Efficient use of different plants } \\
\text { - Industries: Forestry \& Paper, Pharmaceutical \& Biotechnology, Retailers, General Industry. }\end{array}$ \\
\hline & & $\begin{array}{l}\text { Enrich and protect plants from wind } \\
\text { and water erosion, chemicals, etc. }\end{array}$ & $\begin{array}{l}\text { Qur'an - } \\
2: 60\end{array}$ & $\begin{array}{ll}\circ & \text { Increase the amount of pesticide residue free products } \\
\circ & \text { Use trees to eliminate pollution \& emissions } \\
- & \text { Industries: Cement, Mining, and Agricultural. }\end{array}$ \\
\hline & & $\begin{array}{l}\text { Responsibility to protect all kinds of } \\
\text { plants, no abuse, or exploitation, or } \\
\text { carelessness, etc. }\end{array}$ & $\begin{array}{l}\text { Qur'an - } \\
2: 205 \\
6: 141\end{array}$ & $\begin{array}{ll}\circ & \text { Use organic foods and fruits } \\
\circ & \text { Use foods and fruits free from insecticide and herbicide } \\
\circ & \text { Used foods to be recyclable, reusable or compostable }\end{array}$ \\
\hline
\end{tabular}




\begin{tabular}{|c|c|c|c|c|}
\hline & & & $\begin{array}{l}15: 19 \\
16: 115\end{array}$ & $\begin{array}{ll}\circ & \text { Zero waste food to landfill } \\
\circ & \text { Reduce waste foods } \\
\circ & \text { Reduce dust load, chlorosis, and necrosis } \\
\circ & \text { Proper use of Fertilizers \& Pesticides } \\
\circ & \text { Launch sustainable agriculture sourcing guidelines } \\
\circ & \text { Deal with organic suppliers who comply with Nature's Choice Standards } \\
- & \text { Industries: Agricultural, Chemicals, Beverage, Food Producers, Pharmaceutical \& } \\
& \text { Biotechnology, Automobiles \& Parts and General Industry. }\end{array}$ \\
\hline \multirow[t]{3}{*}{ Animals } & & $\begin{array}{l}\text { Source of meat, hair, leather, wool, } \\
\text { medicine, perfume, and as a mode } \\
\text { of transportation, etc. }\end{array}$ & $\begin{array}{l}\text { Qur'an - } \\
\text { 6: } 139 \\
\text { 42:12-13 }\end{array}$ & $\begin{array}{l}\text { Efficient use of Animals and their products } \\
\text { - Industries: Pharmaceutical \& Biotechnology, Beverage, Food Producers, Food \& Drug } \\
\text { Retailers, General Industry, and Travel \& Tourism. }\end{array}$ \\
\hline & & Fair use and consumption & $\begin{array}{l}\text { Qur'an - } \\
6: 118-119 \\
16: 14-16 \& \\
115\end{array}$ & $\begin{array}{l}\text { Integrate animal sourcing and sustainability policy into all canned fish/meat, ready meals, } \\
\text { processed ones } \\
\text { - Industries: Beverage, Food Producers, and Food \& Drug Retailers. }\end{array}$ \\
\hline & & $\begin{array}{l}\text { Like other resources, need to be } \\
\text { respected, protected, and benefit } \\
\text { without exploitation or abuse, etc. }\end{array}$ & $\begin{array}{l}\text { Qur'an - } \\
2: 168 \text { \& } 205 \\
5: 1-2 \\
6: 38 \\
20: 54\end{array}$ & $\begin{array}{ll}\circ & \text { Achieve MSC certified or green-rated for fish species (e.g. cod, haddock, tuna, salmon, prawns) } \\
\circ & \text { Zero harm to animals } \\
\circ & \text { Zero waste/abuse } \\
\circ & \text { Lunch products containing certified sustainable palm oil } \\
\circ & \text { Deal with organic suppliers who comply with Nature's Choice Standards } \\
\circ & \text { Industries: Pharmaceuticals \& Biotechnology, Food Producers, Food \& Drug Retailers, } \\
\text { Aerospace \& Defence and General Industry. }\end{array}$ \\
\hline \multirow[t]{2}{*}{$\begin{array}{l}\text { Other-related } \\
\text { Resources }\end{array}$} & & $\begin{array}{l}\text { Benefit from the massive uses of } \\
\text { these resources, mainly the non- } \\
\text { living resources (e.g., Mountains, } \\
\text { Stars, and Moon) }\end{array}$ & $\begin{array}{l}\text { Qur'an - } \\
10: 67 \\
15: 16 \\
16: 15\end{array}$ & $\begin{array}{ll} & \text { Use solar panels to produce electricity } \\
\circ & \text { Use biofuels as a natural source of energy } \\
\circ & \text { Invest in solar panels to create green heat and power } \\
\circ & \text { Banning on space-based weapons } \\
\circ & \text { Reduction of offensive forces } \\
- & \text { Industries: Aerospace \& Defence, Personal Goods, Banks \& Financial Services, Media, Travel } \\
& \text { \& Tourism, Electricity, Construction \& Materials, Automobiles \& Parts and General Industries. }\end{array}$ \\
\hline & & $\begin{array}{l}\text { Like all living things, these } \\
\text { resources also deserve respect, } \\
\text { protection, and care }\end{array}$ & $\begin{array}{l}\text { Qur'an }- \\
5: 90 \\
17: 27 \\
21: 16\end{array}$ & $\begin{array}{ll} & \text { Zero harm, zero waste or abuse } \\
\circ & \text { Extend green IT and R\&D Eco-programmes to care these scarce resources } \\
\circ & \text { Efficient allocation of resources } \\
\circ & \text { Avoiding extravagant consumption of resources } \\
\circ & \text { Proper use of Fertilizers \& Pesticides } \\
\text { - } & \text { Industries: Chemicals, Cement, Mining, Beverage, Food Producers, Media, Travel \& Tourism, } \\
\text { and Banks \& Financial Services. }\end{array}$ \\
\hline
\end{tabular}


In the business sphere, water is an important element in the production, consumption, and distribution functions of a society (e.g. oil and gas, food industry, agricultural and transportation; gas, and water and multi-utilities, travel and tourism industries). Maintaining water across the globe requires fair and efficient usage of water at an individual and collective level. According to the Islamic ethics, as seen in Table 3, the business practice function in a society must utilise concrete measures for proper usage and fair distribution of freshwater, and eliminate wastewater (e.g. Qur'an 2:49, 54, 60).

The farming and agriculture industry is one of the largest consumers of water. The use of freshwater is a cycle of overuse, waste, pollution, and scarcity of freshwater. Many of the reasons for water problems are related to poor water resource-management practices. For instance, the over-consumption of water from rivers leads to water shortages and problems of salinisation downstream. The irrigation systems and practices are also responsible for the depletion of local freshwater sources and the salinisation of watered land. The scarcity of freshwater reflects the demand for directing human actions to apply water security policy and protecting water supplies. In this context, the Qur'anic ethics offer some guidelines for using and protecting water (see, Qur'an 43:11; 50:9; 54:11-13, 49). The prophet Mohammed prevented his companions from an over-consumption of water in performing ablution (which is a required practice before each prayer), saying: "Conserve water even if you are on the banks of a running stream".

In the food industry, water also plays a significant role at sugar factories where it is used for cleaning, heating, cooling and transportation. These factories could benefit from the Qur'anic principles (e.g. Qur'an $2: 205 ; 7: 31 ; 12: 49 ; 16: 10,114)$ and put in place a water efficiency programme. This would make a significant reduction in water use, maximise recycled condensation for cooling purposes, identify opportunities for reusing and recycling water, and promote a reliance on other sources of water rather than freshwater.

In the mining, and oil and gas corporations, water is used in a wide range of activities including mineral processing, dust suppression, slurry transport, coaling systems and employee requirements (ICMM, 2012; IPIECA, 2005). For the sustainable long-term success of such industries, all constituents across the world (e.g. Anglo American, AREVA, BHP Billiton, Rio Tinto, Barrick, Xstrata Copper, etc.) are strongly expected to share the commitment and responsibility for protecting water now and in the future. This 
includes preparing and developing close-circuit programmes that maximise water conservation. The oil and gas companies should also commit to finding a healthy balance between the water needs of human beings, agriculture, local communities and their own needs. This could be achieved by developing a water management programme to be used in this industry to: (i) protect both land-based water resources and the marine water; (ii) help unearth and tap new sources of water; (iii) seek ways in which used water has been recycled in agricultural irrigation (for example); (iv) use reclaimed waste-water or lower-grade natural water in its industrial processes rather than freshwater; and (v) reduce its impact by treating and monitoring our wastewater before discharge.

As the operations of these crucial industries are often located in different countries, these programmes should consider the significant competing municipal, agricultural, and industrial demands, and the very different cultural and spiritual perspectives on the role of water (ICMM 2012; IPIECA 2005; Tlaiss, 2015). By adopting the Islamic ethics of the water resource, mining corporations can decrease water pollution problems including acid mine drainage, metal contamination, and increased sediment levels in streams. (e.g. Qur'an 2:60). According to Kula (2001) the conservation of water is one of the most valuable commodities in the Biblical and Qur'anic lands and is mentioned in many Hadiths. For Muslims, it is forbidden to discharge sewage into rivers and all water wells must be conserved by eliminating all possibly polluting activities (Kula, 2001; see also, Qur'an 2:168, 172; 7:31; 71:11-12; Ali et al., 2000; Sidani and Al Ariss, 2015).

Under the current system of market-driven economic globalisation, there are no restrictions placed on where investments can go to harvest natural resources. Economic globalisation integrates the economies of nationstates into a single unified market, intensifying natural resource exploitation and worsening every existing environmental crisis. For Muslims, water is one of these resources and a gift from God for the life of humans and other living things; without it, the entire ecosystem will come to an end (Wohlwend, 2000). Multinational corporations working in third-world countries in desert climates, therefore, are required to make water preservation a priority in their business strategies such as recycling wastewater, reducing freshwater consumption, fixing leaky areas, and eliminating leaking heavy metals into rivers.

As for air, the anthropogenic climate change due to the pollution of the air by greenhouse gases and other contaminants is now considered as a major environmental problem. It occurs largely as a result of the 
burning of fossil fuels, emissions from industrial operations, the destruction, clearance, and burning of forests. As a result, climate change has observable ecological changes in global mean surface temperature, sea level, ocean circulation, precipitation patterns, etc. Air pollution is also caused by these greenhouse gases and leads to hazardous problems in the health of all living things (Mehraj and Bhat, 2013). The World Health Organisation (WHO) estimates that, globally, at least two million people every year die prematurely due to health effects (e.g. aggravated respiratory and cardiovascular diseases) caused by air pollutants. One of the major sources of air pollution is the automobiles industry, as $60 \%$ of air pollution is caused by vehicles (Baby et al., 2008). The cement industry is another key contributor to air pollution. The inflight releases of cement factories consist of sulphur dioxide, nitrogen oxides and carbon emissions. This cement dust contains heavy metals like chromium, nickel, cobalt, lead, and mercury pollutants hazardous to the biotic environment and its components (Baby et al., 2008; WBCSD, 2012). Similarly, other high impact industries (e.g. chemicals, mining, oil and gas, tobacco, and construction and materials industries) also generate huge amount of emissions from a number of sources including combustion processes, materials handling, and chemical reactions.

As such, business industries are required to reduce harmful air pollution and global warming, ensuring compliance with air quality regulations by setting new ethical regulations and embodying concrete measures that rely on new technologies to reduce all types of emissions during the production and distribution stages. Also, corporations are required to set their own absolute targets aimed at reducing significant emissions, use more natural gas (green power) than electricity to reduce carbon emissions, build wind turbines to produce green energy, reduce road miles, and eliminate ozone depletion. In this context, Qur'an teaches Muslims to respect God's creations, including air, and maintain the balance He created in the environment and its element. God commands people "Do not cause corruption on the earth" (Qur'an 2:11; see also Qur'an 2:164, 205; 30:41, 46; 42:33; 44:38-39; 54:49), and the prophet Mohammed said, "There must be neither harm nor the imposition of harm". Embedding these Islamic ethics into the organisational sustainable culture can help in facilitating air quality initiatives and increase the commitment of individuals to minimise air pollutants; thus improving health and safety for themselves, customers, suppliers, communities, and other living things.

As Table 3 exhibits, land, as an environmental resource, is more likely to be physically disturbed, creating eyesores (e.g. soil erosion, waste-rock piles, open pits, natural habits, disturbance and fragmentation, landfill, 
and damage to buildings and roads), by business practice in many industries such as farming and agriculture, food producers, forestry and paper, travel and tourism, aerospace and defence, cement, oil and gas, mining, chemicals, construction and materials. Such disturbances to the landscape may contribute to the decline of wildlife and plant species in an area. Further, it is possible that many of the pre-mining surface features cannot be replaced after extraction and removal ceases (Dong et al., 2014; Khan et al., 2014; Labuschagne et al., 2005). Qur'anic environmental verses and related Prophetic teachings define several implications for business practice. For example, the Qur'an calls all human beings to refrain from cutting or destroying trees and polluting land. Rather, they are encouraged to fairly utilise and protect the land (Qur'an 2:60; 7:56; 29:36) by sending waste to landfill, integrating biodiversity management into business practices to prevent and rehabilitate bad impacts to land and its plants, and launching sustainable agriculture guidelines (Qur'an 2:22; 5:88; 15:19; 67:15; see also Ali et al., 2000; Sidani and Al Ariss, 2015; Tlaiss, 2015).

The prophet Mohammed and his four caliphs were very keen to advise their governors to be more concerned with the physical development of the land and to protect the sacred nature of soil. The prophet not only encouraged the sustainable use of fertile lands, He also advised his followers of the benefits of making unused land productive by planting trees, sowing seeds, and irrigating dry lands as charitable deeds. He said, "Whoever brings dead land to life, that is, cultivates wasteland, for him is a reward therein". Similarly, business managers, environmental groups, and policy-makers can follow these Islamic teachings to maintain the productivity of the soil, and not expose it to erosion by wind and flood in building, farming, grazing, forestry, and mining. They can also follow the Islamic sustainable land practices, which do not bring about its degradation, but preserve and enhance its fertility.

As shown in Table 3, various industrial sectors contribute to degradation of environmental components including plant vegetation. For example, industries such as farming and agricultural, mining, cement, forestry and paper, food producers, food retailers, tobacco, travel and tourism have adverse impacts on plants such as dust load, chlorosis and necrosis, through various activities starting from extracting activity to consuming activity (Kumar et al., 2008). These activities not only add various contaminants to the environment, but also disrupt the total ecosystem of the area. Another important industry - paper products is critical to society for enhancing literacy and cultural development. However, without changing the current 
business practices of paper production and consumption habits, the rising demand for paper threatens the earth's last remaining natural forests and endangered wildlife.

According to Islam, consumption behaviour depends on the efficient use of natural resources and the reduction of waste, which guarantees a good environmental performance. God says, "Do not squander your wealth wastefully" (Qur'an 17:26). The prophet Mohammed said, "There is no Muslim who plants a tree or sows a field for a human, bird, or animal eats from it, but it shall be reckoned as charity from him". He also said, "If you have a sapling, if you have the time, be certain to plant it, even if Doomsday starts to break forth", in relation to planting trees and protecting them. The first Caliph, Abu Bakr, for example, used to instruct his army not to cut down trees or kill animals except (fairly) for food purpose in enemy territory (Kula, 2001).

Islamic environmental ethics can assist business units and their mangers in avoiding significant criticism by: (i) reducing their deforestation rate and its negative implications for climate change and biodiversity; (ii) maximising the use of recycled fibres and sourcing virgin fibre from credibly certified natural plantations; (iii) using clean technology to minimise paper products' negative impacts on the environment; (iv) embedding sustainable consumption practices into our daily practices; and (v) supporting responsible finance across this industry (see Qur'an 2:60, 267; 6:141; 7:166; 12:47-49). Furthermore, mining, oil and gas exploration in Bangladesh, Cameroon, India, Indonesia, Egypt, Saudi Arabia, and other developing countries causes several threats to forests. Corporations are required to stop deforestation in order to pave the way for the industrial projects and find dead lands to build roads, dams, houses, and other large construction projects. Travel and tourism companies around the world could also use these Islamic teaching to adopt "ecotourism", and this will lead to "reforestation" (see DEFRA, 2014; Qur'an 15:19-21; 44:38; 52:19; 54:49). Finally, governments and policy-makers can also play an important role for protecting plants from unlawful intrusion by farmers, ranchers, and miners, by logging enforced rules and regulations. These rules could include terminating illegal sawmills, the seizure of illegal timber, and financial penalties.

In Qur'an, animals are regarded as: living beings in their own right, glorifying God and attesting to his power and wisdom, and creatures subjected in the service of the human being (Bagader et al., 1994). Therefore, Islam places certain obligations upon the human being concerning the use and care of animals, which s/he 
will be held accountable for on the Day of Judgment. In business practice, pharmaceutical companies cannot replace all animal experiments in the near future. However, they can constantly improve the care and use of animals and develop procedures that reduce and/or replace animal experiments. Additionally, experiments on living animals should only be carried out when no other proper alternative methods are available, and the expected benefits to humans should outweigh the costs to the animals (Qur'an 2:172-73, 205; 7:31; 23:2122; 40:79-80; 54:49; see also, DEFRA and Animal and Plant Health Agency websites). Islamic environmental ethics can also assist corporate responsibility reporting standard-setters (e.g. GRI and DEFRA) in setting new reporting guidelines, thus enabling companies to provide appropriate information regarding the welfare of animals, efficiency, safety, and toxicology from testing in both animals and/or individuals before approving a new drug or treatment (see Table 3).

Travel and tourism companies that practice hunting tourism (e.g. dolphin-based tourism) cause biological imbalances, negative impacts, and dangerous habitats by hunting animals. Islam forbids using animals and birds for targets when practicing shooting. The prophet Mohammed cursed anyone who made a living thing into a target for practicing hunting, saying, "Whoever kills a bird or anything else without its due right, God would ask him about it". The reply was: "O Messenger of God! What is its due right?" He said, "To kill it for food ... and do not sever its head, and throw it". With this in mind, travel and tourism companies are required to adopt eco-tourism to protect wild animals, rare birds, and other environmental resources.

As for other natural resources, Table 3 illustrates different industrial sectors that are corrupting all natural resources including non-living things. For example, travel and tourism, media, banks and financial services, support services, telecommunication, etc., have great negative impacts on natural resources when they increase consumption and/or misuse these scarce and non-renewable resources. The mining, and travel and tourism industries, for example, have potential threats to many natural areas around the world. The activities of these industries and tourists' habits lead to impacts such as land degradation, air pollution, expulsion into sea, natural habits loss, exploitation of local resources, and noise (Kline, 2001). Also, the military industry and its aerospace and defence companies have an aggressive impact on the structure and chemical composition of outer space. Thus, the constituents of these industries can find Qur'anic ethics useful to inform their strategies of natural resource management, monitoring the technological race towards outer space, banning space-based weapons and reducing offensive forces (e.g. nuclear weapons), thus moving 
towards an era of nature-based business, eco-business, and sustainable responsible enterprise (Qur'an 5:78; $10: 5,67 ; 16: 15-16 ; 30: 41)$.

\section{Conclusion}

In Islam, the Qur'an visualises business activity as a social useful function for humanity and society, thus forming a standpoint for views involving respect for the human being, the fair treatment of animals and plants, a balanced consumption of resources, responsible ownership and goals for business, and the code of ethics of business practitioners. Qur'anic ethics for environmental responsibility are founded upon the human/business-environment (i.e. living and non-living things) relationship. According to this divine relationship, human being does not own the elements of the environment. Rather, God is the creator, sustainer, and ultimate owner of the entire eco-environment. However, human beings are the most honourable, favoured species created by God, performing the noble role of the Supreme Being's vicegerent of God on Earth, with all resources at his disposal through trust. Any brutality towards the environment is punishable in this, and in the life thereafter, as God created the world in complexity, beauty, and harmony; and is knowledgeable of every action taking place on Earth. With this relationship in mind, disposal of resources should be undertaken responsibly, considering the wellbeing of every living creature, as nobody has the approval to destroy or waste God-given resources. Damage of all forms and kinds is prohibited in Islam, evidenced by Prophet Mohammed saying, "There shall be no damage and no infliction of damage". This reveals the extent to which Islamic legislation is concerned about the protection of human beings and the conservation of his surrounding social and physical environment against all forms of damage, exploitation, and pollution; thus enhancing the welfare of all created beings across all generations. It is noticeable in daily life how the environment is rapidly being exploited by the acts of human beings, with their footprints found everywhere on Earth. The urgent need for action is clear. Therefore, each and every human being, as a beneficiary, has a religious (or ethical) duty to take care of all elements of the environment given to them, and restore it for future generations (e.g. Ali et al., 2000; Brammer et al., 2007; Mele, 2009; Schouten et al., 2014; Sidani and Al Ariss, 2015; Yasmin et al., 2014).

Religions, with special reference to Islam, have been (to some extent) ignored in global environmental debates and negotiations. For Islam, as Kula (2001) argues, this is possibly owing to Muslims' lack of 
interest in environmental issues. Kamla (2009) further adds that the role of Islam has been negatively portrayed as biased, and as a threat to emancipation and social justice rather than a solution; this may have led to it being disregarded by other powers, making fulfilment of their purpose impossible (Elmelki and Ben Arab, 2009). Yet, if already existing environmentalism approaches, after many years of discussions and agreements, prove ineffective (or fail) to resolve the environmental problems (Kamla, 2009) and even with the enormous amount of environmental protection legislation passed (Kader et al., 1983), it is time for religions (for their powerful influence on behaviours) to step in and take an active, genuine role in addressing this matter. This is especially critical as Muslim nations are developing and expanding economically, and if they followed the classical industrial development path, this would eventually lead to environmental disasters of major magnitude (Bagader et al., 1994). Thus, a need has arisen for a means of economic development that is less damaging.

Remembering the sacred nature of different elements helps to change the bad habits of individuals in dealing with an environment that has arisen from over-indulgent, unsustainable lifestyles and waste. These changes in habits help to preserve the environment for all living beings and for future generations (Kula, 2001; Muhammad et al., 2010). ${ }^{1}$ This is to be enforced by educating believers in positive environmental conduct. From the normative point of view, this should be the responsibility of every individual on Earth. According to Islam, Qur'anic ER is a normative (with practical application) subject, which sets several judgements concerning what is right and wrong; what ought to be, or not, be done. It provides spiritual guidance and aspirations to both Muslims and non-Muslims alike, while facing the various environmental challenges and looking for solutions thereof. All individual activities extend beyond oneself, affecting the rest of the society's welfare and interests. Therefore, all possible means should be utilised to call all individuals to commit themselves to Qur'anic ethics, morals, and manners (or their own religious instructions or cultural inspirational guidance) in dealing with all elements of the environment (e.g. Brammer et al., 2007; Cui et al., 2015; Graafland et al., 2006; Hoivik and Mele, 2009; Mele, 2009; Oumlil and Balloun, 2009; Rice, 1999).

It is argued that human responsibility to God implies and entails human responsibility to the communities (Yasmin et al., 2014). Islam requires individuals (and in turn organisations) to be environmentally

\footnotetext{
${ }^{1}$ However, Barlas (2009) argues that the absence of civil rights and liberties in most Muslim states makes discussions on such issues with the public difficult; therefore shifting people's attitudes and behaviour is challenging.
} 
responsible to others in the nature and its elements. This environmental ethic and stewardship mostly comes from theo-centrism, and therefore humans are the guardians of the earth as entrusted by God. O'Riordan (1989) explains the relationship between God, human beings, and nature, requiring human beings to act according to a code of ethics to deal with, benefit from, and care for, nature and its resources. This code of ethics is informed by religious concerns, and this fact enhances the way in which users of earthly resources see this responsibility and stewardship principals. In Islam, humans have a role to play in preserving the natural resources, by merely using these resources when necessary to reflect their responsibility to God. Consequently, the order, harmony, and ecological stability of the environment should be maintained (Kamla et al., 2006; Kula, 2001).

This study, however, has three limitations. The first derives from the textual analysis of the Qur'an, i.e. it is significant but still not enough to cover the primary sources of Islamic law, the Qur'an and Sunnah. The second limitation is that the textual analysis covers only the environmental themes. Therefore, it may be worthwhile extending the analysis to include social, economic, and governance themes. Finally, this study focuses on a single religion. It was beyond the scope of this paper to examine similarities and differences in ER concept in different religions. Yet, these limitations open several venues for future research.

Both quantitative and qualitative studies of powerful role of religions and the impact of religious teachings on individual attitudes towards environment and its components should be conducted. Future researchers could, therefore, focus on: (i) exploring the ER concept in teachings of the prophet Mohammed and the extent to which they are important in Muslim majority markets; (ii) investigating the extent to which organisations (and individuals) are influenced by Islamic teachings in their environmental performance and behaviour; (iii) revisiting theories informed by the prior ER research to test their applicability in religious contexts and thus possibly developing a moral and spiritual framework; (iv) examining similarities and differences among religions in the context of ethics for environmental responsibility; (v) exploring the ER concept within the sayings and actions of Prophets; (vi) developing a practical framework for applying, for example, Qur'anic ethics of environmental responsibility; and (vii) proposing ways of integrating religious based environmental ethics into various business education in an attempt to produce green graduates/citizen 


\section{Acknowledgements}

The authors would like to acknowledge the kind guidance of the editor (Professor Domenec Mele), and the four anonymous reviewers for their constructive comments and invaluable suggestions throughout the review process. 


\section{References}

Abdallah, W., and Murtuza, A. 2005. The Implications of the Compatibility between Corporate Social Responsibility \& Islamic Antecedents for Accountability and Governance.' Paper presented at the International Annual Meeting of the American Accounting Association, San Francisco, California, 710 August 2005.

Abdelzaher, D., and Abdelzaher, A. 2015. 'Beyond Environmental Regulations: Exploring the Potential of "Eco-Islam” in Boosting Environmental Ethics Within SMEs in Arab Markets.' Journal of Business Ethics, (September), 1-15. DOI 10.1007/s10551-015-2833-8.

Abeng, T. 1997. Business Ethics in Islamic Context: Perspectives of a Muslim Business Leader. Business Ethics Quarterly, 7: 47-54.

Abou El-Fadl, K. 2003. The Human Rights Commitment in Modern Islam. Human Rights and Responsibilities. Oxford: Oneworld Publications.

Al-Attas, N. 1993. Islam and Secularism. Kuala Lumpur: International Institute of Islamic Thought and Civilization (ISTAC).

Al-Ghazali, A. 1901. Al-mustasfa min 'ilm al-usul. Al-Matba'ah Al-Amiriyyah: Egypt.

Ali, A., R. Camp., and M. Gibbs. 2000. 'The Ten Commandments Perspective on Power and Authority in Organizations.' Journal of Business Ethics, 26: 351-361.

Al-Juwayni, A. 1979. Al-burhan fi usul al-fiqh. Dar Al-Ansar: Cairo, Egypt.

Al-Najjar, U. 2008. Maqasid al-Shari'ah bi ab'adin jadidah. Dar Al-Gharb Al-Islami: Beirut.

Al-Qaradawi, Y. 1985. The Lawful and the Prohibited in Islam. Islamic Book Trust: Kuala Lumpur.

Al-Qaradawi, Y. 2000. Safeguarding the environment in Islamic Sharia. Al-Khaleej.

Al-Sabouny, M. 1978. Safawt altafaseer: Tafseer Qur'an karim. Cairo: Dar Al-Sabouny for printing and publication.

ARCWORLD. 2011. TANZANIA: Fishermen say no to dynamite - using Islamic environmental principles. Available at http://www.arcworld.org/projects.asp?projectID=170 (Access date 1 February 2016).

Aribi, Z., and Gao, S. 2012. 'Narrative Disclosure of Corporate Social Responsibility in Islamic Financial Institutions.' Managerial Auditing Journal, 27 (2): 199-222.

Babcock, H. 2009a. 'Assuming Personal Responsibility for Improving the Environment: Moving towards a New Environmental Norm.' Harvard Environmental Law Review, 33: 117-75.

Babcock, H. 2009b. 'Global Climate Change: A Civic Republican Moment for Achieving Broader Changes in Environmental Behaviour.' Pace Environmental Law Review, 26 (1): 1-18.

Babcock, H. 2009c. 'Civic Republicanism Provides Theoretical Support for Making Individuals More Environmentally Responsible.' Notre Dame Journal of Law, Ethics and Public Policy, 23: 515-36.

Baby, S., Singh, N., Shrivastava, P., Nath, S., Kumar, S., Singh, D., and Vivek, K. 2008. 'Impact of dust emission on plant vegetation of vicinity of cement plant.' Environmental Engineering and Management Journal, 7(1): 31-35

Bagader, A., El-Sabbagh, A., Al-Gayand, M., Samarrai, M., and Llewellyn, O. 1994. 'Environmental Protection in Islam.' IUCN Environmental Policy and Law Paper No. 20.http://cmsdata.iucn.org/downloads/eplp_020reven.pdf.

Balali, R., Keulortz, J., and Korthals, M. 2009. 'Reflexive water management in arid regions: The case of Iran.’ Environmental Values, 18(1): 91-112.

Banerjee, S. 2001. 'Managerial perceptions of corporate environmentalism: Interpretations from industry and strategic implications for organisation.' Journal of Management Studies, 38: 489-513.

Banerjee, S. 2002. 'Corporate environmentalism: The construct and its measurement.' Journal of Business Research, 55: 177-191. 
Barlas, A. 2009. 'The Qur'an, Shari'a, and Women's Rights'. In 'Re-imagining the Shari'a: Theory, Practice, and Muslim Pluralism.' Paper presented at the University of Warwick in Venice, Italy, 13-16 September 2009.

Barrow, C. 2005. Environmental Management and Development. Routledge, London.

Beck, U. 1992. Risk society: Towards a new modernity. London: Sage.

Beck, U. 1999. World risk society. Cambridge: Polity Publications.

Beekun, R., and Badawi, J. 2005. 'Balancing Ethical Responsibility among Multiple Organisational Stakeholders: The Islamic Perspective.' Journal of Business Ethics, 60: 131-145.

Belal, A., Abdelsalam, O., and Nizamee, S. 2015. 'Ethical Reporting in Islamic Bank Bangladesh Limited (1983-2010).'Journal of Business Ethics, 129: 769-784.

Benston, G. 1982. 'Accounting and Corporate Accountability.' Accounting, Organisations and Society, 7(2): $87-105$.

Brammer, S., Williams, G., and Zinkin, J. 2007. 'Religion and Attitudes to Corporate Social Responsibility in a Large Cross-Country Sample.' Journal of Business Ethics, 71: 229-43.

Brown, D., Vetterlein, A., and Roemer-Mahler, A. 2010. 'Theorizing Transnational Corporations as Social Actors: An analysis of corporate motivations.' Business and Politics, 12: 1-37.

Byrne, E. 2011. 'Business Ethics Should Study Illicit Businesses: To Advance Respect for Human Rights.' Journal of Business Ethics, 103: 497-509.

Campbell, T. 2006.'A Human Rights Approach to Developing Voluntary Codes of Conduct for Multinational Corporations.' Business Ethics Quarterly, 16 (2): 255-69.

Catasús, B., Lundgren, M., and Rynnel, H. 1997. 'Environmental managers' views on environmental work in a business context'. Business Strategy and the Environment, 6: 197-205.

Cui, J., Jo., H., and Velasquez, M. 2015. 'The Influence of Christian Religiosity on Managerial Decisions Concerning the Environment.' Journal of Business Ethics, 132: 203-231.

DEFRA 2014. Protecting Plant Health: A Plant Biosecurity Strategy for Great Britain. Department for Environment Food \& Rural Affairs. https://www.gov.uk/government/uploads/system/uploads/attachment_data/file/307355/pb14168-planthealth-strategy.pdf.

Deuraseh, N. 2009. 'Maintaining a Healthy Environment: An Islamic Approach.' European Journal of Social Sciences, 8 (4): 524-31.

Donaldson, T. 1982.Corporations and Morality. Englewood Cliffs, N. J.: Prentice Hall Inc.

Donaldson, T., and T.Dunfee. 1994. 'Toward a Unified Conception of Business Ethics: Integrative Social Contracts Theory.' Academy of Management Review, 19 (2): 252-84.

Dong, S., Burritt, R., and Qian, W. 2014. 'Salient stakeholders in corporate social responsibility reporting by Chinese mining and minerals companies.' Journal of Cleaner Production, 84:59-89.

Dusuki, A. 2008. 'What Does Islam Say about Corporate Social Responsibility?' Review of Islamic Economics, 12 (1): 5-28.

Dusuki, A., and Abdullah, N. 2007. 'Maqasid al-Shariah, Maslahah, and Corporate Social Responsibility.' The American Journal of Islamic Social Sciences, 24(1): 25-45.

Egri, C., and Pinfield, L. 1996. Organizations and the biosphere: ecologies and environments. In Clegg, S. R., Hardy, C. and Nord, W. R. (Eds), Handbook of Organization Studies. London: Sage.

Ekwueme, C., Egbunike, C., and Onyali, C. 2013. 'Benefits of Triple Bottom Line Disclosures on Corporate Performance: An Exploratory Study of Corporate Stakeholders.' Journal of Management and Sustainability, 3(2): 79-91.

Entine, J. 1995. 'Rain-forest chic.' Toronto Globe Mail Rep Bus: 41- 52. 
Elkington, J. 1997. Cannibals with forks - Triple bottom line of 21st century business. Stoney Creek, CT: New Society Publishers.

Elmelki, A., and Ben Arab, M. 2009. Ethical Investment and the Social Responsibility of the Islamic Banks. International Business Research, 2 (2): 123-30.

Farman, J. 1990. Halocarbons and stratospheric ozone - a warning from Antartica. In D. J. R. Angell, J. D. Comer, \& M. L. N. Wilkinson (Eds.), Sustaining earth: Response to the environmental threat (pp. 7178). London: Macmillan.

Farook, S., Hassan, M., and Lanis, R. 2011. 'Determinants of Corporate Social Responsibility: the Case of Islamic Banks.' Journal of Islamic Accounting and Business Research, 2 (2): 114-141.

Forbes, L., and Jermier, J. 2010. 'The new Corporate Environmentalism and The Ecology of Commerce.' Organisation and Environment, 23(4): 465- 481.

Freeman, R. E., Pierce, J., and Dodd, R. 2000. Environmentalism and the new logic of business: how firms can be profitable and leave our children a living planet. Oxford, Oxford University Press.

Freeman, R., Harrison, J., Wicks, A., Parmar, B., and De Colle, S. 2010. Stakeholder Theory: The State of the Art. London: Cambridge University Press.

Gladwin, T., Kennelly, J., and Krause, T. 1995. 'Shifting paradigms for sustainable development: implications for management theory and research.' Academy of Management Review, 20: 874-907.

Goel, P. 2010. 'Triple bottom line reporting: An analytical approach for corporate sustainability.' Journal of Finance, Accounting, and Management, 1(1): 27-42.

Graafland, J., Kaptein, M., and Schouten, C. 2006. 'Business Dilemmas and Religious Belief: An Explorative Study among Dutch Executives.' Journal of Business Ethics, 66: 53-70.

Gray, R. 2010. 'Is accounting for sustainability actually accounting for sustainability ... and how would we know? An exploration of narratives, of organisations and the planet.' Accounting, Organizations and Society, 35(1): 47-62.

Gray, R., Walters, D., Bebbington, J., and Thompson, I. 1995a. 'The Greening of Enterprise: An Exploration of the (Non) Role of Environmental Accounting and Environmental Accountants in Organizational Change.' Critical Perspectives on Accounting, 6: 211-39.

Gray, R., Kouhy, R., and Lavers, S. 1995b. 'Corporate Social and Environmental Reporting: A Review of the Literature and a Longitudinal Study of UK Disclosure.' Accounting, Auditing and Accountability Journal, 8(2): 47-77.

Haniffa, R. 2002. 'Social Reporting Disclosure: An Islamic Perspective.' Indonesian Management and Accounting Research, 1(2): 128-46.

Haniffa, R., and Hudaib, M. 2007. 'Exploring the Ethical Identify of Islamic Banks via Communication in Annual Reports.' Journal of Business Ethics, 76: 97-116.

Hart, S. 1995. 'A natural-resources-based view of the firm.' Academy of Management Review, 20: 986-1014.

Hart, S. 1997. 'Beyond greening: strategies for a sustainable world.' Harvard Business Review, 75(1): 6676.

Hasan, M. 2002.Worldview Orientation and Ethics: A Muslim Perspective. In Ethics in Business and Management: Islamic and Mainstream Approaches, edited by AbulHasan M. Sadeq. London: Asean Academic Press.

Hawken, P. 1992. 'The ecology of commerce.' Inc.: 93-100.

Hawken, P. (1993). The ecology of commerce: A declaration of sustainability. New York, NY: Harper Business.

Henriques, A. 2007. CSR, sustainability and the triple bottom line. In Henriques, A., and Richardon, J. (Eds). The Triple Bottom Line: Does it All Add Up? London: Earthscan. (pp. 26-33).

Hoivik, H., and Mele, D. 2009. 'Can an SME Become a Global Corporate Citizen? Evidence from a Case Study.' Journal of Business Ethics, 88: 551-563. 
Holsti, O. 1969. Content analysis for the social science. Reading Massachusetts, Menlo Park, CA and London: Addison-Wesley.

Hope, A., and Jones, C. 2014. 'The impact of religious faith on attitudes to environmental issues and carbon capture and storage (CCS) technologies: A mixed methods study.' Technology in Society, 38: 48-59.

Hsieh, N. 2004. 'The Obligations of Transnational Corporations: Rawlsian Justice and the Duty of Assistance.' Business Ethics Quarterly, 14 (4): 643-61.

ICMM 2012. Water management in mining: a selection of case studies. International Council on Mining \& Metals. http://www.icmm.com/document/3660.

IPIECA 2005. Water Resource Management in the Petroleum Industry. The International Petroleum Industry Environmental Conservation Association. http://www.ipieca.org/publication/water-resourcemanagement-oil-and-gas-industry.

Jackson, T. 2009. Prosperity without growth: Economics for a finite planet. London: Earthscan.

Jennings, P., and Zandbergen, P. 1995. 'Ecologically sustainable organizations: an institutional approach.' Academy of Management Review 20:1015-1052.

Jermier, J., Forbes, L., Benn, S., and Orsato, R. 2006. The new corporate environmentalism and green politics. In S. R. Clegg, C. Hardy, T. B. Lawrence \& W. Nord (Eds.), The Sage handbook of organization studies (2nd ed., pp. 618-650). London, England: Sage.

Jusoff, K., and Abu Samah, S. 2011. 'Environmental Sustainability: What Islam Propagates.' World Applied Sciences Journal, 12: 46-53.

Kader, A., Al Sabbagh, A., Al Glenid, M., and Samarrai, M. 1983. Islamic Principles for the Conservation of the Natural Environment. IUCN Environmental Policy and Law Paper No. 20.https://www.iucn.org/about/work/programmes/environmental_law/elp_resources/elp_res_publicati ons/?uPubsID=746.

Kamla, R. 2007. 'Critically Appreciating Social Accounting and Reporting in the Arab Middle East: A Postcolonial Perspective.' Advances in International Accounting20: 105-77.

Kamla, R. 2009.'Critical Insights into Contemporary Islamic Accounting.' Critical Perspectives on Accounting 20: 921-32.

Kamla, R., Gallhofer, S., and Haslam, J. 2006. 'Islam, Nature and Accounting: Islamic Principles and the Notion of Accounting for the Environment.' Accounting Forum, 30: 245-65.

Khan, S., V. Chouhan., B. Chandra., and S. Goswami. 2014. 'Sustainable accounting reporting practices of Indian cement industry: An exploratory study.' Uncertain Supply Chain Management 2:61-72.

Kim, D., Fisher, D., and McCalman, D. 2009. 'Modernism, Christianity, and Business Ethics: A Worldview Perspective.' Journal of Business Ethics, 90: 115-121.

Kline, J. 2001. Tourism and natural resource management: a general overview of research and issues. United States Department of Agriculture, Forest Service, Pacific Northwest Research Station. http://www.fsl.orst.edu/lulcd/Publicationsalpha_files/Kline_2001_GTR506.pdf.

Krippendorff, K. 2004. Content Analysis: An Introduction to its Methodology. 2nd ed. London: SAGE Publications.

Kula, E. 2001. 'Islam and Environmental Conservation.' Environmental Conservation, 28 (1): 1-9.

Kumar, S., Singh, N., Kumar, V., Sunisha, B., Preeti, S., Deepali, S., and Nath, S. 2008. 'Impact of Dust Emission on Plant Vegetation in the Vicinity of Cement Plant.' Environmental Engineering and Management Journal, 7:31-35.

Labuschagne, C., Brent, A., and van Erck, R. 2005.'Assessing the sustainability performance of industries.' Journal of Cleaner Production, 13:373-385.

Leary, M., and Kowalski, M. 1990. 'Impression Management: A Literature Review and Two-Component Model.' Psychological Bulletin, 107(1): 34-47.

Lewis, M. 2001. 'Islam and Accounting.' Accounting Forum, 25 (2): 103-27. 
Lloyd, R., Oatham, J., and Hammer, M. 2007. The 2007 Global Accountability Report. One World Trust.http://www.un.org/en/pseataskforce/docs/2007_global_accountability_report.pdf.

Lu, X. 2009. 'Business Ethics and Karl Marx's Theory of Capital—Reflections on Making Use of Capital for Developing China's Socialist Market Economy.' Journal of Business Ethics, 91: 95-111.

Lutz, M. 2002. 'Social Economics, Justice and the Common Good.' International Journal of Social Economics, 29 (1/2): 26-44.

McFerran, B., Aquino, K., and Duffy, M. 2010. 'How Personality and Moral Identity Relate to Individuals' Ethical Ideology.' Business Ethics Quarterly, 20 (1): 35-56.

Maali, B., Casson, P., and Napier, C. 2006. 'Social Reporting by Islamic Banks.' ABACUS, 42 (2): 266-289.

Mehraj, S., and Bhat, G. 2013. Cement Factories, Air Pollution and Consequences. Department of Environmental Sciences \& Centre of Research for Development, University of Kashmir, Jammu and Kashmir, India. http://www.sciencepub.net/book/00065_book_1_65.pdf.

Mele, D. 2009. 'Integrating Personalism into Virtue-Based Business Ethics: The Personalist and the Common Good Principles.' Journal of Business Ethics, 88: 227-244.

Menon, A., and Menon, A. 1997. Enviropreneurial Marketing Strategy: The Emergence of Corporate Environmentalism as Market Strategy. Journal of Marketing, 61: 51-67.

Milne, M., and Gray, R. 2013. 'W(h)ither Ecology? The Triple Bottom Line, the Global Reporting Initiative, and Corporate Sustainability Reporting.' Journal of Business Ethics, 118: 13-29.

Mohammed, J. 2013. 'An Islamic Perspective of Corporate Social Responsibility.' GBSR e-Journal of Business, Economics and Social Sciences.http://www.worldresearchconference.com/journals/gbsr/EJOURNAL/104\%20JOURNAL\%2 OGBSR.pdf.

Muhammad, G., Shah-Kazemi, R., and Ahmed, A. 2010. The Holy Qur'an and the Environment. Jordan: The Royal Aal Al-Bayt Institute for Islamic Thought.

Norman, W., and MacDonal, C. 2004. Getting to the bottom of the triple bottom line. Business Ethics Quarterly, 2(14), 243-262.

Novo Nordisk. 2008. Bioethics in Action: Animals in Pharmaceutical research and development. Novo Nordisk Pharmaceutical Company. http://www.novonordisk.com/images/science/Bioethics/Downloads/Bioethics_Animals\%20UK_2509.pdf.

O'Riordan, T. 1989. The Challenge for Environmentalism. In R. Peet and N. Thrift (Eds.), New Models in Geography. London: Unwin Hyman: 77-102.

Othman, R., Thani, A., Ghani, E. 2009. 'Determinants of Islamic Social Reporting Among Top ShariahApproved Companies in Bursa Malaysia.' Research Journal of International Studies, 12: 1-17.

Oumlil, A., and Balloun, J. 2009. 'Ethical Decision-Making Differences Between American and Moroccan Managers.' Journal of Business Ethics, 84: 457-478.

Park, C. 2001. The Environment: Principles and Applications, $2^{\text {nd }}$ edn. Routledge, London.

Pew Research Center 2012. The Global Religious Landscape: A report on the size and distribution of the world's major religious groups as of 2010. http://www.pewforum.org/files/2014/01/global-religionfull.pdf.

Platonova, E. 2013. 'Corporate Social Responsibility from an Islamic Moral Economy Perspective: A Literature Survey.' Afro Eurasian Studies, 2 (1/2): 272-97.

Porritt, J. 2007. Capitalism as if the world matters. London: Earthscan.

Pretty, J. 1990. Agricultural pollution: from costs and causes to sustainable practices. In D. J. R. Angell, J. D. Comer, and M. L. N.Wilkinson (Eds.), Sustaining Earth: response to the environmental threat (pp. 6071). London: Macmillan. 
Ramasamy, B., Yeung, M., and Au, A. 2010. 'Consumer Support for Corporate Social Responsibility (CSR): The Role of Religion and Values.' Journal of Business Ethics, 91: 61-72.

Rice, G. 1999. 'Islamic Ethics and the Implications for Business.' Journal of Business Ethics, 18: 345-58.

Rice, G. 2006. 'Pro-environmental Behavior in Egypt: Is there a Role for Islamic Environmental Ethics?' Journal of Business Ethics, 65: 373-390.

Rizk, R. 2014. 'Islamic environmental ethics.' Journal of Islamic Accounting and Business Research, 5(2): 194-204.

Roughton, G. (2007). 'The Ancient and the Modern: Environmental Law and Governance in Islam.' Columbia Journal of Environmental Law, 32: 99-139.

Rosen, H. 1995. 'The evil empire: the real scoop on Ben and Jerry's crunchy capitalism.' New Republic,: 2250 .

Savitz, A., and Weber, K. 2006. The Triple Bottom Line: How Today's Best-run Companies Are Achieving Economic, Social and Environmental Success - And How You Can Too. John Wiley \& Sons, Inc.

Schneider, S. (1990). The changing climate and problems of prediction. In D. J. R. Angell, J. D. Comer, and M. L. N.Wilkinson (Eds.), Sustaining earth: Response to the environmental threat (pp. 33-42). London: Macmillan.

Schouten, C., Graafland, J., and Kaptein, M. 2014. 'Religiosity, CSR Attitudes, and CSR Behavior: An Empirical Study of Executives' Religiosity and CSR.' Journal of Business Ethics, 123: 437-459.

Shrivastava, P. 1995. 'The role of corporations in achieving ecological sustainability.' Academy of Management Review, 20:936-960.

Sidani, Y., and Al Ariss, A. 2015. 'New Conceptual Foundations for Islamic Business Ethics: The Contributions of Abu-Hamid Al-Ghazali.' Journal of Business Ethics, 129: 847- 857.

Smithson, P., Addison, K., and Atkinson, K .2008. Fundamentals of the Physical Environment. Routledge, London.

Srnka, K., Gegez, A., and Arzova, S. 2007. 'Why Is it (Un-) ethical? Comparing Potential European Partners: A Western Christian and An Eastern Islamic Country- On Arguments Used in Explaining Ethical Judgments.' Journal of Business Ethics, 74: 101-118.

Stern, N. 2006. The economics of climate change. Cambridge: Cambridge University Press.

Tlaiss, H. 2015. 'How Islamic Business Ethics Impact Women Entrepreneurs: Insights from Four Arab Middle Eastern Countries.' Journal of Business Ethics, 129: 859-877.

UN Global Compact 2000. The Ten Principles of the UN Global Compact.http://www.unglobalcompact.org/abouttheGC/thetenprinciples/index.html.

WBCSD 2012. The Cement Sustainability Initiative: 10 years of progress- moving on to the next decade. World Business Council for Sustainable Development. http://csiprogress2012.org/CSI ProgressReport FullReport.pdf.

Wettstein, F. 2012. 'CSR and the Debate on Business and Human Rights: Bridging the Great Divide.' Business Ethics Quarterly, 22 (4): 739-70.

Wilkinson, M., and Woodin, S. 1990. Acid precipitation. In D. J. R. Angell, J. D. Comer, and M. L.N.Wilkinson (Eds.), Sustaining earth: Response to the environmental threat (pp. 33-42). London: Macmillan.

Wohlwend, B. 2000. Institutional Means to Implement Integrated Water Resources Management. Working Group on Legal Aspects of Management of Shared Water Resources: Sharm El-Sheikh, Egypt.

Yasmin, S., Haniffa, R., and Hudaib, M. 2014. 'Communicated Accountability by Faith-Based Charity Organisations.' Journal of Business Ethics, 122: 103-123.

Zeffane, R., Polonsky, M., and Medley, P. 1995. 'Corporate environmental commitment: developing the operational concept.’ Business Strategy Environment, 13(4):17-28. 
Zinkin, J. 2007. 'Islam and CSR: A Study of the Compatibility Between the Tenets of Islam, the UN Global Compact and the Development of Social, Human and Natural Capital.' Corporate Social Responsibility and Environmental Management, 14: 206-218.

Zubairu, U., Sakariyau, O., and Dauda, C. 2011. 'Social Reporting Practices of Islamic Banks in Saudi Arabia.' International Journal of Business and Social Science, 2 (23): 193-205.

Zulfikar, Y. 2012. 'Do Muslims Believe in Protestant Work Ethic than Christians? Comparison of People with Different Religious Background Living in the US.' Journal of Business Ethics, 105: 489-502. 